\title{
Mechanism of Action of Escherichia coli Heat Stable Enterotoxin in a Human Colonic Cell Line
}

Patrick A. Huott, Wilson Liu, James A. McRoberts, Ralph A. Giannella, and Kiertisin Dharmsathaphom

Division of Gastroenterology, Department of Medicine, University of California at San Diego Medical Center, University of California, San Diego, California 92103; Division of Digestive Diseases, Department of Internal Medicine, University of Cincinnati Medical Center, Cincinnati, Ohio 45267; and Veterans Administration Hospital, Cincinnati, Ohio 45220

\begin{abstract}
Escherichia coli heat stable enterotoxin $\left(\mathrm{ST}_{\mathrm{a}}\right)$ caused $\mathrm{Cl}^{-}$secretion across $T_{84}$ cell monolayers in a dose-dependent manner only when applied to the apical membrane surface and not when applied to the basolateral surface. Measurement of cAMP, cGMP, and free cytosolic $\mathrm{Ca}^{2+}$ in response to $S T_{\text {a }}$ suggested that cGMP alone mediated the $\mathrm{Cl}^{-}$secretory response. Studies utilizing blockers of the $\mathrm{Na}^{+}, \mathrm{K}^{+}$-ATPase pump, a $\mathrm{Na}^{+}, \mathrm{K}^{+}, \mathrm{Cl}^{-}$cotransport system, a $\mathrm{K}^{+}$channel, and a $\mathrm{Cl}^{-}$channel suggest that all of them participate in the $\mathrm{Cl}^{-}$ secretory process induced by $\mathrm{ST}_{\mathrm{a}}$. The results suggest that the $\mathrm{Cl}^{-}$secretory response induced by $\mathrm{ST}_{\mathrm{a}}$ is mediated by cGMP after the enterotoxin binds to its receptor on the apical membrane. The enterotoxin, by increasing cGMP, opens a $\mathrm{K}^{+}$ channel on the basolateral membrane as well as a $\mathrm{Cl}^{-}$channel on the apical membrane. The activation of these ion exit mechanisms, together with activations of the $\mathrm{Na}^{+}, \mathrm{K}^{+}, \mathrm{Cl}^{-}$cotransporter and the $\mathrm{Na}^{+}, \mathrm{K}^{+}$-ATPase pump drives $\mathrm{Cl}^{-}$exit through the $\mathrm{Cl}^{-}$channel on the apical membrane.
\end{abstract}

\section{Introduction}

Escherichia coli heat stable enterotoxin $\left(\mathrm{ST}_{\mathrm{a}}\right)^{1}$ causes intestinal secretion of fluid and electrolytes and an increase in cellular cGMP levels $(1,2)$. Studies by other investigators suggest that cGMP is the secondary messenger mediating the secretory response induced by the enterotoxin (3-6). The mechanism of action beyond the step of cGMP formation, including the transport pathways involved in the secretory process, has not been fully elucidated. Evidence in the literature suggests that cGMP inhibits a "neutral" $\mathrm{Na}^{+}, \mathrm{Cl}^{-}$absorptive process, and stimulates an "electrogenic" $\mathrm{Cl}^{-}$secretory mechanism (4-6). Our laboratory has utilized a cultured human colonic epithe-

Address reprint requests to Dr. Dharmsathaphorn, Division of Gastroenterology, UCSD Medical Center (H-811-D), 225 West Dickinson Street, San Diego, CA 92103.

Presented in abstract form at the 86th Annual Meeting of the American Gastroenterological Association in San Francisco, May 1986. 1988.

Received for publication 10 July 1986 and in revised form 3 March

1. Abbreviations used in this paper: $F_{0}$, fluorescence in absence of calcium; $F_{s}$, fluorescence in saturating calcium; $I_{s c}$, short circuit current; $\mathrm{ST}_{\mathrm{a}}, E$. coli heat stable enterotoxin; VIP, vasoactive intestinal polypeptide.

J. Clin. Invest.

(c) The American Society for Clinical Investigation, Inc.

0021-9738/88/08/0514/10 \$2.00

Volume 82, August 1988, 514-523 lial cell line, $\mathrm{T}_{84}$, as a model system to study colonic secretion (7-18). The cell line, derived from a lung metastasis of a human colonic carcinoma, resembles crypt cells morphologically $(7,8)$ and secretes $\mathrm{Cl}^{-}$in response to a variety of secretagogues whose actions are mediated via cAMP- or $\mathrm{Ca}^{2+}$-related mechanisms $(7,9-14,17,18)$. The $\mathrm{T}_{84}$ cell line is a secretory cell line without absorptive function and thus may allow better elucidation of the secretory mechanism. Previous studies indicate that $\mathrm{Cl}^{-}$secretion across $\mathrm{T}_{84}$ cell monolayers results from a coordinated interaction of four transport pathways: (a) The $\mathrm{Na}^{+}, \mathrm{K}^{+}$-ATPase pump which provides the driving force, $(b)$ a $\mathrm{Na}^{+}, \mathrm{K}^{+}, \mathrm{Cl}^{-}$cotransport system that serves as the $\mathrm{Cl}^{-}$uptake pathway $(9,11,13),(c) \mathrm{A} \mathrm{K}^{+}$channel that serves to recycle the $\mathrm{K}^{+}(10,11,13,15)$, and $(d) \mathrm{A} \mathrm{Cl}^{-}$channel that serves as the $\mathrm{Cl}^{-}$exit step $(11,16)$. The first three pathways are located basolaterally while the $\mathrm{Cl}^{-}$exit channel is located apically. Regulation by secretagogues is at the $\mathrm{K}^{+}$and/or $\mathrm{Cl}^{-}$channels $(10-13,15,16)$. These channels are regulated directly and independently of the $\mathrm{Na}^{+}, \mathrm{K}^{+}, \mathrm{Cl}^{-}$cotransporter or the $\mathrm{Na}^{+}, \mathrm{K}^{+}-$ ATPase pump. cAMP (vasoactive intestinal polypeptide, VIP, or $\mathrm{PGE}_{1}$ ) opens both the apically localized $\mathrm{Cl}^{-}$channel as well as a basolaterally localized $\mathrm{K}^{+}$channel. On the other hand, $\mathrm{Ca}^{2+}$ (carbachol) opens another type of $\mathrm{K}^{+}$channel on the basolateral membrane and we could not detect opening the apical $\mathrm{Cl}^{-}$channel with the technique we used. The interaction between these two different mediators (cAMP and $\mathrm{Ca}^{2+}$ ) results in a synergistic action that promotes increased $\mathrm{Cl}^{-}$secretion $(12,13)$. Because $\mathrm{ST}_{\mathrm{a}}$, which increases cGMP, may activate $\mathrm{Cl}^{-}$secretion by a mechanism different from that activated by cAMP or $\mathrm{Ca}^{2+}$, we decided to investigate the mechanism of action of $\mathrm{ST}_{\mathrm{a}}$ and compare the results with cAMP- or $\mathrm{Ca}^{2+}$-mediated secretory responses.

\section{Methods}

Growth and maintenance of $\mathrm{T}_{84}$ cells, preparation of the collagencoated (Nuclepore, Pleasanton, CA) filters, transepithelial electrolyte transport studies, ${ }^{86} \mathrm{Rb}^{+}$efflux from monolayers mounted in Ussing chambers and extraction and measurement of cAMP followed the procedures previously described $(9-11,15,16)$. Extraction and measurement of cGMP used similar procedures as those described for cAMP except that cGMP standard and cGMP antisera from New England Nuclear (Boston, MA) were used instead of the cAMP standard and cAMP antisera. The antisera were specific for CAMP or cGMP and there was no cross-reactivity (see Results).

Short-circuit current and transepithelial chloride transport studies. Although the detailed methodology has been described repeatedly elsewhere, it appears appropriate to define the short-circuit current $\left(I_{s c}\right)$ for readers. Our experiments were carried out across $T_{84}$ monolayers mounted between two fluid-filled reservoirs (Ussing chambers) that allowed active transport mechanisms to occur unimpeded while eliminating passive forces that might confound the observation. $I_{\mathrm{sc}}$ is the electrical current needed to nullify the electrical potential differences 
(P.D.) resulted from active transport of ions; the $I_{\mathrm{sc}}$ maintained the P.D. at zero. In our experimental system, P.D. across $\mathrm{T}_{84}$ cell monolayers have been shown to result from the transepithelial secretion of chloride ions since they are the only ions transported transcellularly by $\mathrm{T}_{84}$ cells. $\mathrm{Cl}^{-}$ions carry negative charges with them. Hence, the amount of $\mathrm{Cl}^{-}$secreted can be easily quantitated by recording the electrical current $\left(I_{\mathrm{sc}}\right)$ needed to nullify the electrical charges carried by $\mathrm{Cl}^{-}$ions from one reservoir to another. For practical purposes readers can equate $I_{\mathrm{sc}}$ with $\mathrm{Cl}^{-}$secretion in this series of studies. Results in Table I support our conclusion in this regard.

Radionuclide efflux and uptake studies. Bumetanide-sensitive and insensitive ${ }^{86} \mathrm{Rb}^{+}$efflux, bumetanide-sensitive ${ }^{86} \mathrm{Rb}^{+}$uptake and ${ }^{36} \mathrm{Cl}^{-}$ uptake were studied to determine the effect of $\mathrm{ST}_{\mathrm{a}}$ on specific ion transport pathways. Radionuclide uptake or efflux was assayed using replicate confluent monolayer cultures of $\mathrm{T}_{84}$ cells attached to $35 \mathrm{~mm}$ culture dishes.

Bumetanide-sensitive and insensitive ${ }^{86} \mathrm{Rb}^{+}$efflux was assayed in the presence of $0.5 \mathrm{mM}$ ouabain as described previously (15) to determine whether the $\mathrm{K}^{+}$channels and/or the $\mathrm{Na}^{+}, \mathrm{K}^{+}, \mathrm{Cl}^{-}$cotransporter were activated. Confluent monolayer cultures of $\mathrm{T}_{84}$ cells were loaded to steady state with ${ }^{86} \mathrm{Rb}^{+}$by incubation for $4 \mathrm{~h}$ in buffer containing $138 \mathrm{mM} \mathrm{NaCl}, 10 \mathrm{mM}$ Hepes-Tris, pH 7.4, $10 \mathrm{mM}$ glucose, $2 \mathrm{mM}$ $\mathrm{RbCl}, 1 \mathrm{mM} \mathrm{MgCl}$, and $0.25 \mu \mathrm{Ci} / \mathrm{ml}^{86} \mathrm{Rb}^{+}$. The monolayers were washed and incubated with buffer containing $140 \mathrm{mM}$ choline chloride, $10 \mathrm{mM}$ Hepes-Tris, $\mathrm{pH} 7.4,1 \mathrm{mM} \mathrm{MgCl}_{2}$, and $0.5 \mathrm{mM}$ ouabain for $1 \mathrm{~h}$. Effluxes were initiated by aspirating this buffer and adding buffer containing $140 \mathrm{mM} \mathrm{NaCl}, 10 \mathrm{mM}$ Hepes-Tris (pH 7.4), $1 \mathrm{mM}$ $\mathrm{MgCl}_{2}$, and $0.5 \mathrm{mM}$ ouabain with or without $0.1 \mathrm{mM}$ bumetanide and with or without $\mathrm{ST}_{\mathrm{a}}$ or VIP. Effluxes were stopped after 15 and $30 \mathrm{~min}$ by washing rapidly four times with ice-cold $100 \mathrm{mM} \mathrm{MgCl} 210 \mathrm{mM}$ Hepes-Tris, pH 7.4.

Bumetanide-sensitive ${ }^{86} \mathrm{Rb}^{+}$uptakes were determined in the presence of ouabain as described previously (9) to assess whether the $\mathrm{Na}^{+}, \mathrm{K}^{+}, \mathrm{Cl}^{-}$cotransport pathway is directly activated by $\mathrm{ST}_{\mathrm{a}}$. The cells were first incubated in $\mathrm{KCl}$ buffer for $1 \mathrm{~h}$ followed by incubation in isotonic sucrose buffer $(241 \mathrm{mM}$ sucrose, $10 \mathrm{mM}$ Hepes-Tris, $1 \mathrm{mM}$ $\mathrm{MgCl}_{2}$ ) containing $0.5 \mathrm{mM}$ ouabain for $1.0 \mathrm{~h}$. This double preincubation procedure eliminated $\mathrm{Na}^{+}, \mathrm{K}^{+}$ATPase activity as well as removing all extracellular ions while maintaining relatively high cellular $\mathrm{K}^{+}$ concentrations $(9,16) .{ }^{86} \mathrm{Rb}^{+}$uptakes were determined after prestimulating the cells with $\mathrm{ST}_{\mathrm{a}}$ in sucrose buffer by aspirating the preincubation buffer and replacing it with uptake buffer $(135 \mathrm{mM} \mathrm{NaCl}, 10 \mathrm{mM}$ Hepes-Tris, pH 7.4, $5 \mathrm{mM} \mathrm{KCl}, 1 \mathrm{mM} \mathrm{MgCl}$ ) containing $2 \mu \mathrm{Ci} / \mathrm{ml}$ ${ }^{86} \mathrm{Rb}^{+}$with or without $0.1 \mathrm{mM}$ bumetanide. The initial rate of ${ }^{86} \mathrm{Rb}^{+}$ uptake under these conditions is largely $(>95 \%)$ bumetanide sensitive and $\mathrm{Na}^{+}$and $\mathrm{Cl}^{-}$dependent (9). Both ${ }^{86} \mathrm{Rb}^{+}$and ${ }^{36} \mathrm{Cl}^{-}$uptakes were terminated using the $\mathrm{MgSO}_{4} /$ sucrose wash procedure described previously $(9,11,15,16)$.

The initial rate of ${ }^{36} \mathrm{Cl}$ uptake mediated by the $\mathrm{Cl}^{-}$channel was estimated using a modification of the method originally reported to test whether the $\mathrm{Cl}^{-}$channel is opened directly by $\mathrm{ST}_{a}(16)$. An example of the method is shown in Fig. 1. Replicate, confluent monolayers of $\mathrm{T}_{84}$ cells were preincubated in $\mathrm{KCl}$ buffer $(140 \mathrm{mM} \mathrm{KCl}, 10 \mathrm{mM}$ Hepes-Tris, pH 7.4, $1 \mathrm{mM} \mathrm{MgCl}$ ). After $1 \mathrm{~h}$ intracellular $\mathrm{K}^{+}$and $\mathrm{Cl}^{-}$ concentrations approached 140 and $100 \mathrm{mM}$, respectively (16). The cells were stimulated with either $\mathrm{ST}_{\mathrm{a}}$ or VIP by preincubating for the stated times in $\mathrm{KCl}$ buffers containing given concentrations of these effectors. ${ }^{36} \mathrm{Cl}^{-}$uptake was assayed by aspirating this preincubation buffer and replacing it with $\mathrm{K}$ gluconate buffer $(140 \mathrm{mM} \mathrm{K}$ gluconate, $10 \mathrm{mM}$ Hepes-Tris, $\mathrm{pH} 7.5,1 \mathrm{mM} \mathrm{Mg}$ gluconate) containing $1 \mu \mathrm{Ci} / \mathrm{ml}$ ${ }^{36} \mathrm{Cl}^{-}\left(1.2 \mathrm{mM}\right.$ final $\left.{ }^{36} \mathrm{Cl}^{-}\right)$. Under these conditions a transient $\mathrm{Cl}^{-}$ diffusion potential is created that favors uptake of ${ }^{36} \mathrm{Cl}^{-}$through an electrogenic (i.e., channel) mediated mechanism (19). When the cells have been stimulated with effectors that open the apically localized $\mathrm{Cl}^{-}$ channels, the time course of ${ }^{36} \mathrm{Cl}^{-}$uptake is biphasic reaching a peak after $90 \mathrm{~s}$ and declining to control values within $6 \mathrm{~min}$. Uptakes are linear during the first $30 \mathrm{~s}$. Triplicate values determined after 5,15 , and $30 \mathrm{~s}$. in the absence of effectors were used to extropolate zero time
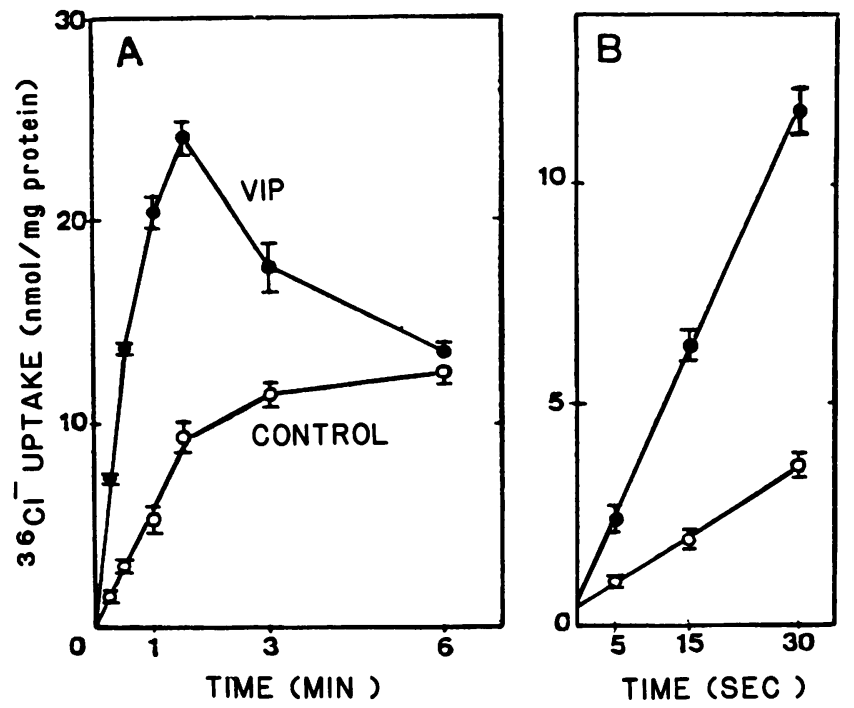

Figure 1. Stimulation by VIP of dilution potential-induced ${ }^{36} \mathrm{Cl}^{-}$uptake. Replicate confluent monolayer cultures of $\mathrm{T}_{84}$ cells on $35 \mathrm{~mm}$ culture plates were incubated for 1.5 to $2 \mathrm{~h}$ in $\mathrm{KCl}$ buffer $(140 \mathrm{mM}$ $\mathrm{KCl}, 10 \mathrm{mM}$ Hepes-Tris, $\mathrm{pH} 7.5,1 \mathrm{mM} \mathrm{MgCl}$ ). The monolayers were then incubated an additional $15 \mathrm{~min}$ in this $\mathrm{KCl}$ buffer in the presence $(\bullet)$ or absence $(0)$ of $10^{-7} \mathrm{M}$ VIP. ${ }^{36} \mathrm{Cl}^{-}$uptakes were initiated by aspirating the preincubation buffer and replacing it with $\mathrm{K}$ gluconate buffer (140 mM K gluconate, $10 \mathrm{mM}$ Hepes-Tris, $\mathrm{pH} 7.5$, $1 \mathrm{mM} \mathrm{Mg}$ gluconate) containing $1 \mu \mathrm{Ci} / \mathrm{ml}^{36} \mathrm{Cl}^{-}(1.64 \mathrm{mM}$ final ${ }^{36} \mathrm{Cl}^{-}$in this experiment). Uptakes were terminated at the given times by washing rapidly (within $5 \mathrm{~s}$ ) four times with $2 \mathrm{ml}$ ice-cold $\mathrm{MgSO}_{4}$-sucrose buffer (137 mM sucrose, $100 \mathrm{mM} \mathrm{MgSO}_{4}, 10 \mathrm{mM}$ Hepes-Tris, $\mathrm{pH} 7.5$ ). ( $A$ ) Points are the average of duplicate determinations and bars the range. $(B)$ Points are the mean of quadruplicate determinations and bars are the standard deviation from the mean.

background levels by linear regression $(<20 \%$ of the control 30 -s time values). Uptakes determined after prestimulation by effectors were terminated after 15 and $30 \mathrm{~s}$ in duplicate. After subtraction of zero time values, and correction for the time increment, these values were averaged. This method insured that initial rates of uptake were measured. Linear regression of the data always gave values of $r>0.92$.

Measurement of free cytosolic $\mathrm{Ca}^{2+}$. The method for free cytosolic calcium $\left(\left[\mathrm{Ca}^{2+}\right]_{i}\right)$ measurement follows that described by Tsien et al. $(20,21)$ with some modifications. $T_{84}$ monolayers were plated and grown as described previously. Monolayers were rinsed free of culture media and then incubated for $15 \mathrm{~min}$ at room temperature in calcium-free Ringer's solution, buffered with $30 \mathrm{mM}$ Hepes containing $1.0 \mu \mathrm{M}$ Fura-2/AM. 5 vol of identical Ringer's buffer containing calcium and Fura-2/AM (1.2 mM and $1.0 \mu \mathrm{M}$, respectively) were then added, and the incubation continued for an additional $75 \mathrm{~min}$ at $37^{\circ} \mathrm{C}$. After the loading incubation, the entire ring assembly was incubated for $15 \mathrm{~min}$ at $37^{\circ} \mathrm{C}$ in the buffer used for fluorescence measurements. This buffer contained: $\mathrm{NaCl} 137.0 \mathrm{mM}, \mathrm{KCl} 5.4 \mathrm{mM}, \mathrm{CaCl}_{2} 1.0 \mathrm{mM}$, $\mathrm{KH}_{2} \mathrm{PO}_{4} 0.4 \mathrm{mM}, \mathrm{MgCl}_{2} 0.5 \mathrm{mM}, \mathrm{MgSO}_{4} 0.4 \mathrm{mM}, \mathrm{NaHCO}_{3} 4.2 \mathrm{mM}$, $\mathrm{Na}_{2} \mathrm{HPO}_{4} 0.3 \mathrm{mM}$, Hepes $10.0 \mathrm{mM}$, and glucose $0.6 \mathrm{mM}$, with the $\mathrm{pH}$ adjusted to 7.4 with $\mathrm{NaOH}$. The final incubation step served to remove any dye remaining outside the cell or in contact with the cell membrane.

Fluorescence measurements were carried out in a fluorescence spectrophotometer (model 650-10S; Perkin-Elmer, Norwalk, CT). Excitation monochromator settings were 340 and $380 \mathrm{~nm}$ with a slit width of $5 \mathrm{~nm}$. Emitted light was collected through a 495-515-nm interference filter with an emission slit of $10 \mathrm{~nm}$. Monolayers were mounted for measurement as follows: the Nuclepore filter holding the monolayer was peeled off the Lexan ring and attached to a polystyrene 
support, which was then placed in a standard $10-\mathrm{mm}$ cuvette. The polystyrene support, with the attached monolayer, was exposed to the same buffer in the cuvette on both the apical and basolateral sides. Orientation of the monolayer within the cuvette itself was $45^{\circ}$ to the excitation beam and angled $10-20^{\circ}$ from the vertical plane to minimize the interference from reflected excitation light. Excitation monochromator settings were changed manually every $10 \mathrm{~s}$ with the wavelength drive control.

Free cytosolic calcium levels were calculated from the equation $\left[\mathrm{Ca}^{2+}\right]_{i}=K_{\mathrm{d}}\left(F_{0} / F_{\mathrm{s}}\right)\left[\left(R-R_{0}\right) /\left(R_{\mathrm{s}}-R\right)\right]$, where $K_{\mathrm{d}}$ is $224 \mathrm{~nm}, F_{0}$ is the fluorescence at $380 \mathrm{~nm}$ in the absence of calcium, $F_{\mathrm{s}}$ is the fluorescence at $380 \mathrm{~nm}$ in saturating calcium, and the experimental ratio, $R$, is obtained by dividing the fluorescence at $340 \mathrm{~nm}$ by that at $380 \mathrm{~nm}$ after subtracting the respective autofluorescence levels. $R_{0}$ is the ratio of the signal at $340 \mathrm{~nm}$ to the signal at $380 \mathrm{~nm}$ in the absence of calcium and $R_{\mathrm{s}}$ is the ratio at saturating calcium. Autofluorescence for individual monolayers was measured at the end of each experiment after the addition of $1 \mathrm{mM} \mathrm{MnCl}{ }_{2}$ and ionomycin $(10 \mu \mathrm{g} / \mathrm{ml})$ to the buffer to allow the $\mathrm{Mn}^{2+}$ to enter the cells and quench the dye signal.

Materials. All radionuclides, cyclic AMP, and cyclic GMP antisera were obtained from New England Nuclear, Boston, MA. $\mathrm{ST}_{\mathrm{a}}$ was prepared and purified by one of the authors, Dr. Ralph Giannella, according to the procedure previously described (22-24). Bumetanide was a gift from Dr. P. W. Feit of Leo Pharmaceutical Products, Ballerup, Denmark. Barium chloride dehydrate was purchased from J. T. Baker Chemical Co., Phillipsburg, NJ. Ouabain was from Fluka Chemical Corp., Hauppauge, NY. 5-Nitro-2-(2-phenylpropylamino)benzoic acid was a gift from Dr. R. F. Greger of Physiologisches Institut, Universitat Freiburg, Freiburg, FRG. Carbachol was from ICN Biochemicals, Cleveland, OH. VIP was a gift from Dr. Jean Rivier of the Salk Institute, La Jolla, CA. Fura-2/AM and Fura-2 pentapotassium salt were purchased from Molecular Probes, Inc., Eugene, OR. Ionomycin was purchased from Calbiochem Biochemicals, La Jolla, CA

Statistical analysis. Student's $t$ tests were used as indicated (25).

\section{Results}

Stimulation of net $C T^{-}$secretion across $T_{84}$ monolayers by $S T_{a}$. The addition of $2.5 \times 10^{-7} \mathrm{M} \mathrm{ST}_{\mathrm{a}}$ to the mucosal bathing solution caused an immediate increase in the $I_{\text {sc }}$, which reached a peak 30 to $35 \mathrm{~min}$ after addition and remained near maximal throughout the study period. Serosal addition of $\mathrm{ST}_{\mathrm{a}}$ had no effect (Fig. 2). The $I_{\mathrm{sc}}$ response to $\mathrm{ST}_{\mathrm{a}}$ was dose dependent with the threshold stimulation occurring at $10^{-8} \mathrm{M}$, and the maximal response at $5 \times 10^{-7} \mathrm{M}$ (Fig. 3). Half maximal stimulation occurred at $\sim 4 \times 10^{-8} \mathrm{M}$. Since our supply of $\mathrm{ST}_{\mathrm{a}}$ was limited, a concentration of $2.5 \times 10^{-7} \mathrm{M}$, which gave a near maximal response, was selected for subsequent studies unless otherwise indicated.

Unidirectional $\mathrm{Na}^{+}$and $\mathrm{Cl}^{-}$flux results are summarized in Table I. The time course of these data correspond to the time course of $I_{s c}$ illustrated in Fig. 2. In the basal state, net flux of $\mathrm{Na}^{+}$and $\mathrm{Cl}^{-}$and $I_{\text {sc }}$ remains at or near zero for more than 100 min (9-14, and Table I, group I). Following the addition of 2.5 $\times 10^{-7} \mathrm{M} \mathrm{ST}_{\mathrm{a}}$, an increase in net chloride secretion was observed and totally accounted for changes in $I_{\text {sc }}$ (Table I, group II). No change in the unidirectional fluxes of $\mathrm{Na}^{+}$was observed after the addition of $\mathrm{ST}_{\mathrm{a}}$. In contrast, both the serosal to mucosal and mucosal to serosal $\mathrm{Cl}^{-}$fluxes increased, with the former being consistently greater, thus resulting in net $\mathrm{Cl}^{-}$ secretion (Table I, group II).

Because of the increase in monolayers' conductance after the addition of $\mathrm{ST}_{\mathrm{a}}$, questions arise as to whether $\mathrm{ST}_{\mathrm{a}}$ increases paracellular permeability. Mannitol fluxes were, therefore,

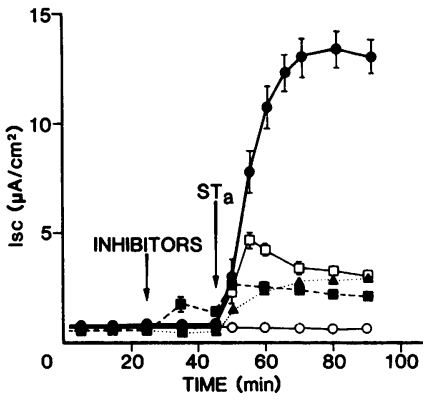

Figure 2. Time course of $I_{\mathrm{sc}}$ response to $E$. coli heat stable enterotoxin $\left(\mathrm{ST}_{\mathrm{a}}\right)$ by $\mathrm{T}_{84}$ monolayers mounted in the Ussing chamber. As shown in Table I, $I_{\mathrm{sc}}$ reflects net $\mathrm{Cl}^{-}$secretion across $T_{84}$ monolayers. $\mathrm{ST}_{\mathrm{a}}$ was added to the mucosal reservoir except for the serosal experiment (o) at 45 min after mounting. Bumetanide or barium chloride, if added, were to

the serosal reservoir, while 5-nitro-2-(2-phenylpropylamino)-benzoic acid was added to the mucosal reservoir. All inhibitor additions were made at 25 min after mounting. The results shown are from the same monolayers in Table I, except for 5-nitro-2-(2-phenylpropylamino)-benzoic acid experiment for which $n=4$ and for the serosal addition of $\mathrm{ST}_{\mathrm{a}}$ for which $n=3$. All three monolayers in which $\mathrm{ST}_{\mathrm{a}}$ was added serosally responded subsequently to mucosal addition with similar results as the group shown here for $\mathrm{ST}_{\mathrm{a}}$ alone. The concentration of $\mathrm{ST}_{\mathrm{a}}$ in all groups was $0.25 \mu \mathrm{M}$. Addition of $0.1 \mathrm{mM}$ bu-

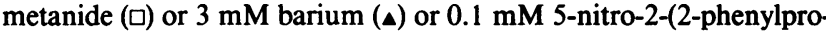
pylamino)-benzoic acid $(₫)$ significantly reduced $\mathrm{ST}_{\mathrm{a}}$-induced $I_{\mathrm{sc}}$ response as compared to that of $\mathrm{ST}_{\mathrm{a}}$ alone (๑). At $3 \mathrm{mM}$, precipitation of barium was visible. Precipitation of barium occurs at concentrations of 3 and $10 \mathrm{mM}$. Therefore, the concentrations were overestimated at these concentrations. 5-Nitro-2-(2-phenylpropylamino)benzoic acid also inhibited the $\mathrm{ST}_{\mathrm{a}}$-induced increase in cGMP.

Thus it is unclear whether its ability to inhibit the $I_{\mathrm{sc}}$ induced by $\mathrm{ST}_{\mathrm{a}}$ was attributable to its effect on the $\mathrm{Cl}^{-}$channel or its effect on cGMP.

carried out as reported previously (8) over the same time frame as for $\mathrm{Na}^{+}$and $\mathrm{Cl}^{-}$fluxes. There was no significant changes of mannitol flux after the addition of $\mathrm{ST}_{\mathrm{a}}: J_{\text {mannitol }}^{m \rightarrow s}$ and $J_{\text {mannitol }}^{s \rightarrow m}$ were $0.002 \pm 0.001,0.003 \pm 0.001 \mu \mathrm{mol} / \mathrm{h} \cdot \mathrm{cm}^{2}$, respectively, in period I-II (prior to the addition of $2.5 \times 10^{-7} \mathrm{M} \mathrm{ST}_{\mathrm{a}}$ ) and $0.003 \pm 0.002,0.003 \pm 0.003 \mu \mathrm{mol} / \mathrm{h} \cdot \mathrm{cm}^{2}$ in period III (after the addition of $\mathrm{ST}_{\mathrm{a}}, n=3$ pairs).

Another question that arose was whether the increase in monolayer's conductance was reversible. When $\mathrm{ST}_{\mathrm{a}}$ antibodies were used to reserve $\mathrm{ST}_{\mathrm{a}}$ 's action in another study (26), monolayers conductance was also reversed to control level in $30 \mathrm{~min}$ $\left(\mathrm{ST}_{\mathrm{a}}\right.$ antibodies reversed $97 \pm 3 \%$ of $\mathrm{ST}_{\mathrm{a}}$-induced increase in $I_{\mathrm{sc}}$ and $93 \pm 7 \%$ of $\mathrm{ST}_{\mathrm{a}}$-induced increase on conductance in that study, $n=3$ ). In another experiment the bathing media were replaced with $\mathrm{ST}_{\mathrm{a}}$-free media after $\mathrm{ST}_{\mathrm{a}}$ had induced an increase in $I_{\mathrm{sc}}$ and conductance. $30 \mathrm{~min}$ after washing $88 \pm 7 \%$ of $\mathrm{ST}_{\mathrm{a}}-$ induced increase in $I_{\mathrm{sc}}$ and $62 \pm 19 \%$ of $\mathrm{ST}_{\mathrm{a}}$-induced increase in

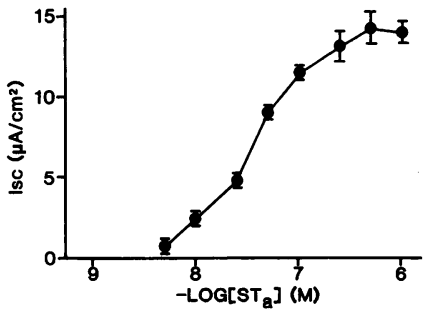

Figure 3. Graded dose effect of $\mathrm{ST}_{\mathrm{a}}$ on the changes in $I_{\mathrm{sc}}$. As shown in Table $I, I_{\mathrm{sc}}$ reflects net $\mathrm{Cl}^{-}$secretion across $\mathrm{T}_{84}$ monolayers. $T_{84}$ monolayers were mounted in the Ussing chamber and $\mathrm{ST}_{\mathrm{a}}$ was added to the mucosal reservoir at the concentration indicated. Only one addition was made to each monolayer. The results are the mean $\pm \mathrm{SE}$ of the peak change in the $I_{\mathrm{sc}}$ within $35 \mathrm{~min}$ after addition of $\mathrm{ST}_{\mathrm{a}}$ and were obtained from four experiments at each concentration. 
Table I. Unidirectional $\mathrm{Na}^{+}$and $\mathrm{Cl}^{-}$Flux in Response to E. coli Heat Stable Enterotoxin $\left(S T_{a}\right)$

\begin{tabular}{|c|c|c|c|c|c|c|c|c|c|c|}
\hline Group & $\begin{array}{l}\text { Experimental } \\
\text { condition }\end{array}$ & $\begin{array}{c}\text { Flux } \\
\text { period }\end{array}$ & $J_{\mathrm{m} \rightarrow \mathrm{s}}^{\mathrm{Na}}$ & $J_{\mathrm{m} \rightarrow \mathrm{m}}^{\mathrm{Na}}$ & $J_{\mathrm{Det}}^{\mathrm{Na}}$ & $J_{\mathrm{m} \rightarrow \mathrm{s}}^{\mathrm{a}}$ & $J_{2 \rightarrow m}^{\mathrm{c}}$ & $J_{\text {net }}^{a}$ & $I_{\boldsymbol{x}}$ & G \\
\hline & & & & $\mu e q \cdot h^{-1} \cdot \mathrm{cm}$ & & & $\mu e q \cdot h^{-1} \cdot \mathrm{cm}^{-2}$ & & $\mu e q \cdot h^{-1} \cdot \mathrm{cm}^{-2}$ & $\mathrm{mS} \cdot \mathrm{cm}^{-2}$ \\
\hline $\mathrm{I}(n=4)$ & $\begin{array}{l}\text { No addition } \\
\text { No addition } \\
\text { No addition }\end{array}$ & $\begin{array}{l}\text { I } \\
\text { II } \\
\text { III }\end{array}$ & $\begin{array}{l}0.32 \pm 0.03 \\
0.29 \pm 0.05 \\
0.27 \pm 0.04\end{array}$ & $\begin{array}{l}0.27 \pm 0.04 \\
0.27 \pm 0.04 \\
0.31 \pm 0.04\end{array}$ & $\begin{array}{r}0.05 \pm 0.03 \\
0.02 \pm 0.02 \\
-0.04 \pm 0.04\end{array}$ & $\begin{array}{l}0.40 \pm 0.03 \\
0.33 \pm 0.02 \\
0.31 \pm 0.02\end{array}$ & $\begin{array}{l}0.43 \pm 0.03 \\
0.36 \pm 0.05 \\
0.41 \pm 0.08\end{array}$ & $\begin{array}{l}-0.03 \pm 0.03 \\
-0.03 \pm 0.05 \\
-0.10 \pm 0.03\end{array}$ & $\begin{array}{l}0.02 \pm 0.00 \\
0.02 \pm 0.00 \\
0.02 \pm 0.00\end{array}$ & $\begin{array}{l}0.46 \pm 0.07 \\
0.44 \pm 0.07 \\
0.48 \pm 0.06\end{array}$ \\
\hline $\mathrm{II}(n=5)$ & $\begin{array}{l}\text { No addition } \\
\text { No addition } \\
\text { ST }_{2}\end{array}$ & $\begin{array}{r}\text { I } \\
\text { II } \\
\text { III }\end{array}$ & $\begin{array}{l}0.28 \pm 0.07 \\
0.40 \pm 0.05 \\
0.30 \pm 0.05\end{array}$ & $\begin{array}{l}0.30 \pm 0.05 \\
0.30 \pm 0.04 \\
0.39 \pm 0.05\end{array}$ & $\begin{array}{r}-0.02 \pm 0.06 \\
0.10 \pm 0.03 \\
-0.09 \pm 0.06\end{array}$ & $\begin{array}{l}0.48 \pm 0.07 \\
0.46 \pm 0.05 \\
0.84 \pm 0.05^{\dagger}\end{array}$ & $\begin{array}{l}0.44 \pm 0.07 \\
0.43 \pm 0.05 \\
1.38 \pm 0.10^{\dagger}\end{array}$ & $\begin{array}{c}0.04 \pm 0.11 \\
0.03 \pm 0.06 \\
-0.53 \pm 0.07^{\dagger}\end{array}$ & $\begin{array}{l}0.03 \pm 0.01 \\
0.04 \pm 0.01 \\
0.47 \pm 0.04^{\dagger}\end{array}$ & $\begin{array}{l}0.54 \pm 0.06 \\
0.56 \pm 0.08 \\
0.98 \pm 0.15^{\dagger}\end{array}$ \\
\hline III $(n=4)$ & $\begin{array}{l}\text { No addition } \\
\text { Bumetanide } \\
\text { Bumetanide plus ST, }\end{array}$ & $\begin{array}{r}\text { I } \\
\text { II } \\
\text { III }\end{array}$ & $\begin{array}{l}0.26 \pm 0.04 \\
0.30 \pm 0.03 \\
0.31 \pm 0.05\end{array}$ & $\begin{array}{l}0.20 \pm 0.05 \\
0.38 \pm 0.04 \\
0.36 \pm 0.01\end{array}$ & $\begin{array}{r}0.06 \pm 0.04 \\
-0.08 \pm 0.04 \\
-0.05 \pm 0.06\end{array}$ & $\begin{array}{l}0.32 \pm 0.04 \\
0.36 \pm 0.05 \\
0.41 \pm 0.07^{*}\end{array}$ & $\begin{array}{l}0.34 \pm 0.04 \\
0.45 \pm 0.03 \\
0.59 \pm 0.04^{*}\end{array}$ & $\begin{array}{l}-0.02 \pm 0.05 \\
-0.09 \pm 0.06 \\
-0.18 \pm 0.03^{*}\end{array}$ & $\begin{array}{l}0.02 \pm 0.00 \\
0.03 \pm 0.01 \\
0.12 \pm 0.01^{\dagger *}\end{array}$ & $\begin{array}{l}0.47 \pm 0.07 \\
0.55 \pm 0.05 \\
0.80 \pm 0.05^{\dagger}\end{array}$ \\
\hline $\operatorname{IV}(n=5)$ & $\begin{array}{l}\text { No addition } \\
\mathrm{BaCl}_{2} \\
\mathrm{BaCl}_{2} \text { plus } \mathrm{ST}_{2}\end{array}$ & $\begin{array}{r}\text { I } \\
\text { II } \\
\text { III }\end{array}$ & $\begin{array}{l}0.29 \pm 0.06 \\
0.38 \pm 0.05 \\
0.28 \pm 0.05\end{array}$ & $\begin{array}{l}0.29 \pm 0.06 \\
0.29 \pm 0.07 \\
0.22 \pm 0.06\end{array}$ & $\begin{array}{l}0.00 \pm 0.04 \\
0.08 \pm 0.03 \\
0.06 \pm 0.05\end{array}$ & $\begin{array}{l}0.40 \pm 0.03 \\
0.45 \pm 0.05 \\
0.79 \pm 0.06^{\dagger}\end{array}$ & $\begin{array}{l}0.34 \pm 0.07 \\
0.39 \pm 0.06 \\
0.85 \pm 0.05^{\dagger} *\end{array}$ & $\begin{array}{c}0.06 \pm 0.06 \\
0.06 \pm 0.02 \\
-0.06 \pm 0.05^{*}\end{array}$ & $\begin{array}{l}0.03 \pm 0.00 \\
0.02 \pm 0.00 \\
0.10 \pm 0.01^{\dagger *}\end{array}$ & $\begin{array}{l}0.48 \pm 0.08 \\
0.49 \pm 0.07 \\
0.69 \pm 0.07\end{array}$ \\
\hline
\end{tabular}

Results are expressed as mean \pm SE. The number of paired monolayers for each experimental group, $(n)$, is indicated in parentheses. Period $I$ is the average of two consecutive 5-min flux periods starting $15 \mathrm{~min}$ after mounting and addition of isotope to the Ussing chambers, and ending just before addition of inhibitors (15-25 min). Period II is the average of two consecutive 5-min flux periods starting 10 min after the addition, if made, of bumetanide or $\mathrm{BaCl}_{2}$ ( $35-45 \mathrm{~min}$ ). Period $\mathrm{III}$ is the average of two consecutive flux periods, one 5-min period and one 10-min period, starting $25 \mathrm{~min}$ after addition of ST, was $0.25 \mu \mathrm{M}$; bumetanide, $0.1 \mathrm{mM}$; and $\mathrm{BaCl}_{2}, 3 \mathrm{mM}$. ${ }^{\dagger} P<0.05$ with Student's unpaired $t$ test as compared to the same period in group I (control). ${ }^{*} P<0.05$ by Student's unpaired $t$ test as compared to the same period in group II (STa alone).

conductance were reversed $(n=7)$. Repeat washing tended to increase monolayer's conductance and might cause a lesser degree of reversal in conductance.

Inhibition of $S T_{a}$-stimulated $C C^{-}$secretion by specific inhibitors of membrane transport. We have previously shown that a loop diuretic, bumetanide, inhibits the basolaterally localized $\mathrm{Na}^{+}, \mathrm{K}^{+}, \mathrm{Cl}^{-}$cotransport system in the $\mathrm{T}_{84}$ cell line (9). This transport pathway serves as the $\mathrm{Cl}^{-}$uptake pathway and its inhibition by bumetanide results in a reversal or inhibition of $\mathrm{Cl}^{-}$secretion mediated by cAMP or $\mathrm{Ca}^{2+}(9,11,13)$. Therefore, bumetanide was used to test the involvement of this cotransport pathway in the $\mathrm{Cl}^{-}$secretory process activated by $\mathrm{ST}_{\mathrm{a}}$.

Serosal addition of $10^{-4} \mathrm{M}$ bumetanide inhibited the action of $\mathrm{ST}_{\mathrm{a}}$ while mucosal addition has little or no effect. As was the case for VIP- and $\mathrm{PGE}_{1}$-induced $\mathrm{Cl}^{-}$secretion, bumetanide incompletely inhibited the action of $\mathrm{ST}_{\mathrm{a}}$. At $10^{-4} \mathrm{M}$ bumetanide, added 20 min before addition of $\mathrm{ST}_{\mathrm{a}}, \sim 20 \%$ of the peak $I_{\mathrm{sc}}$ induced by $S \mathrm{~T}_{\mathrm{a}}$ persisted (Fig. 2). In the presence of bumetanide, the time course of the response to $\mathrm{ST}_{\mathrm{a}}$ showed that the late effect of $\mathrm{ST}_{\mathrm{a}}$, rather than the initial effect, was inhibited. Thus the time course of the response was shorter in duration, reaching a peak within $10 \mathrm{~min}$. Unidirectional $\mathrm{Na}^{+}$ and $\mathrm{Cl}^{-}$fluxes in the presence of bumetanide are summarized in Table I, group III. $10^{-4} \mathrm{M}$ bumetanide significantly reduced the $\mathrm{ST}_{\mathrm{a}}$-induced increases in serosal to mucosal as well as mucosal to serosal $\mathrm{Cl}^{-}$flux resulting in reduced net $\mathrm{Cl}^{-}$secretion with a corresponding decrease in $I_{\text {sc }}$. Bumetanide, by itself, had no effect on the basal $\mathrm{Na}^{+}$or $\mathrm{Cl}^{-}$fluxes (group III, period II). Bumetanide also reversed the action of $\mathrm{ST}_{\mathrm{a}}$ when added after $\mathrm{ST}_{\mathrm{a}}$ had elicited a response (data not shown).

Barium, a $\mathrm{K}^{+}$channel blocker, has been found to inhibit $\mathrm{Cl}^{-}$secretion in a number of epithelia $(10,27,28)$. In $\mathrm{T}_{84}$ cells, barium inhibits a $\mathrm{K}^{+}$recycling mechanism on the basolateral membrane. $\mathrm{A} \mathrm{K}^{+}$exit mechanism is intimately involved in the $\mathrm{Cl}^{-}$secretory process mediated by cAMP or $\mathrm{Ca}^{2+}$ and appears to serve as a site regulated by a number of secretagogues (10,
$11,13,15)$. Therefore, barium was used to test whether $\mathrm{Cl}^{-}$ secretion induced by $\mathrm{ST}_{\mathrm{a}}$ required the same $\mathrm{K}^{+}$recycling mechanism. We found that $\mathrm{BaCl}_{2}$ added serosally inhibited the increase in $I_{\mathrm{sc}}$ induced by $\mathrm{ST}_{\mathrm{a}}$, while mucosal addition had little or no effect. At a concentration of $3 \mathrm{mM}, 80 \%$ of the effect of $\mathrm{ST}_{\mathrm{a}}$ was inhibited (Fig. 2). The results of unidirectional and net $\mathrm{Na}^{+}$and $\mathrm{Cl}^{-}$fluxes, summarized in Table I, group IV, confirm that barium inhibited net $\mathrm{Cl}^{-}$secretion. Similar to bumetanide, barium by itself had no effect on basal $I_{\text {sc }}$ or on unidirectional $\mathrm{Na}^{+}$and $\mathrm{Cl}^{-}$fluxes (see group IV, period II). In contrast to bumetanide, barium had little effect on the increase in mucosal to serosal $\mathrm{Cl}^{-}$movements induced by $\mathrm{ST}_{\mathrm{a}}$. Unidirectional $\mathrm{Cl}^{-}$fluxes in both directions were increased by $\mathrm{ST}_{\mathrm{a}}$ regardless of the presence of barium, while net $\mathrm{Cl}^{-}$flux was reduced to near zero. The inhibitory effect of barium on the action of $\mathrm{ST}_{\mathrm{a}}$ was reversible. Barium also reversed the action of $\mathrm{ST}_{\mathrm{a}}$ when added after $\mathrm{ST}_{\mathrm{a}}$ had elicited a response (data not shown). Other putative $\mathrm{K}^{+}$channel blockers including apamin $\left(10^{-6} \mathrm{M}\right)$, tetraethylammonium chloride $\left(10^{-2} \mathrm{M}\right)$, and 4-aminopyridine $\left(10^{-2} \mathrm{M}\right)$ did not exhibit an inhibitory effect. Quinidine $\left(3 \times 10^{-4} \mathrm{M}\right)$ caused a rise in $I_{\mathrm{sc}}$ before exerting an inhibitory action. The results are similar to those observed with secretagogues such as VIP or PGE which increase cellular cAMP levels.

Ouabain, a $\mathrm{Na}^{+}, \mathrm{K}^{+}$-ATPase inhibitor, also inhibited and reversed $\mathrm{ST}_{\mathrm{a}}$-induced $I_{\mathrm{sc}}$ when added to the serosal reservoir at a concentration of $10^{-4} \mathrm{M}$. When ouabain was added after $\mathrm{ST}_{\mathrm{a}}$ had elicited a response, $\sim 80 \%$ inhibition was observed $20-25$ min after the addition of ouabain and 85 to $90 \%$ inhibition at $45 \mathrm{~min}$. Similar results were obtained with ouabain pretreatment (data not shown).

5-Nitro-2-(2-phenylpropylamino)-benzoic acid, an anthracene derivative, is a recently developed potent blocker of the $\mathrm{Cl}^{-}$channel. This $\mathrm{Cl}^{-}$channel blocker, which was tested initially in the thick ascending limb of the loop of Henle (29), is much less effective in the $\mathrm{T}_{84}$ cells requiring $10^{-4} \mathrm{M}$ to cause significant inhibition of $\mathrm{Cl}^{-}$secretion. 5-Nitro-2-(2-phenyl- 
propylamino)-benzoic acid did inhibit $\mathrm{ST}_{\mathrm{a}}$-induced $I_{\mathrm{sc}}$ when added to the mucosal reservoir at a relatively high concentration of $10^{-4} \mathrm{M}$ (Fig. 2). This putative $\mathrm{Cl}^{-}$channel blocker also reversed the $I_{s c}$ induced by $\mathrm{ST}_{\mathrm{a}}$ when added after $\mathrm{ST}_{\mathrm{a}}$ had elicited a response (data not shown). Unfortunately, at the concentration of the agent used in this study, $10^{-4} \mathrm{M}$, the compound partially inhibited the rise in cellular cAMP induced by VIP and the rise in cellular cGMP induced by $\mathrm{ST}_{\mathrm{a}}$ (unpublished observations) and caused the results to be inconclusive. Any conclusion related to 5-nitro-2-(2-phenylamino)benzoic acid's effect in blocking $\mathrm{Cl}^{-}$secretion must remain inconclusive as long as it is unknown as to what extent the inhibition is due to an effect on the $\mathrm{Cl}^{-}$channels or due to an effect on cGMP.

Evidence for $S T_{a}$-induced $\mathrm{K}^{+}$efflux on the basolateral membrane, and its similarity to a cAMP-induced effect. To verify the existence of a $\mathrm{K}^{+}$efflux pathway and to test if barium inhibited this process, monolayers were preloaded with ${ }^{86} \mathrm{Rb}^{+}$(as a tracer for $\mathrm{K}^{+}$) and mounted in the Ussing chamber. This method allows the measurement of ${ }^{86} \mathrm{Rb}^{+}$efflux across both the apical and basolateral surfaces while $\mathrm{Cl}^{-}$secretion, as reflected by the $I_{\mathrm{sc}}$, is simultaneously monitored $(10,11,13)$. The apparent first order rate constants, along with the mean $I_{\mathbf{s c}}$ and conductance of the monolayers for each time interval in which additions were made, are shown in Table II. In the basal state, the rate of ${ }^{86} \mathrm{Rb}^{+}$efflux into the mucosal bath was $\sim 10$ to 20 -fold less than that into the serosal bath. The addition of $\mathrm{ST}_{\mathrm{a}}$ increased the rate of ${ }^{86} \mathrm{Rb}^{+}$efflux into the serosal bath by approximately two-fold, while the amount of ${ }^{86} \mathrm{Rb}^{+}$ efflux into the mucosal bath remained small. The increase in basolateral membrane ${ }^{86} \mathrm{Rb}^{+}$efflux rate was totally inhibited by the prior addition of $3 \mathrm{mM}$ barium to the serosal bathing medium. $3 \mathrm{mM}$ barium had no effect on ${ }^{86} \mathrm{Rb}^{+}$efflux in the basal state. Net $\mathrm{Cl}^{-}$secretion induced by $\mathrm{ST}_{\mathrm{a}}$, as indicated by the $I_{\mathrm{sc}}$, was also inhibited by barium. The graded dose effect for the inhibition of $\mathrm{ST}_{\mathrm{a}}$-induced $I_{\mathrm{sc}}$ by barium is shown in Fig. 4. This effect is identical to that seen with barium inhibition of VIP- or PGE $\mathrm{E}_{1}$-induced $I_{\mathrm{sc}}(10,11)$, but differs from the inhibitory action of barium on A23187- or carbachol-induced $I_{s c}$. The $I_{\mathrm{sc}}$ response of A23187 is more resistant to barium inhibition, while the $I_{\mathrm{sc}}$ response of carbachol is totally unaffected to barium $(10,13)$. It should be noted that at concentrations of 3 $\mathrm{mM}$ or above, barium precipitated in the solution and therefore the effective concentration was lower than indicated.

We then quantitated the magnitude of ${ }^{86} \mathrm{Rb}^{+}$efflux induced by a combination of $\mathrm{ST}_{\mathrm{a}}$ and carbachol as well as by $\mathrm{ST}_{\mathrm{a}}$ and VIP (Table III). An additive effect between $\mathrm{ST}_{\mathrm{a}}$ and either VIP or carbachol would confirm that the compounds act via different pathways while the lack of an additive effect would suggest that they act via the same pathway. ${ }^{86} \mathrm{Rb}^{+}$efflux induced by the combination of $\mathrm{ST}_{\mathrm{a}}$ and carbachol was additive, while ${ }^{86} \mathrm{Rb}^{+}$efflux induced by the combination of $\mathrm{ST}_{\mathrm{a}}$ and VIP was not different from ${ }^{86} \mathrm{Rb}^{+}$efflux induced by $\mathrm{ST}_{\mathrm{a}}$ or VIP alone (Table III). These findings suggest the presence of two different types of $\mathrm{K}^{+}$efflux pathways, one activated by $\mathrm{ST}_{\mathrm{a}}$ or VIP, and the other activated by carbachol. The former is sensitive to barium as described above and previously (10), while the latter is less so (13). In addition, the increase in $I_{\text {sc }}$ induced by the combination of $\mathrm{ST}_{\mathrm{a}}$ and carbachol was greater than the predicted additive response (potentiated), while the increase in $I_{\mathrm{sc}}$ induced by $\mathrm{ST}_{\mathrm{a}}$ and VIP was less than additive and approximated that induced by VIP alone (Table III). At a concentration of VIP $\left(10^{-8} \mathrm{M}\right)$ that gave a maximal response, $10^{-6} \mathrm{M}$ $\mathrm{ST}_{\mathrm{a}}$ caused no further increase in $I_{\mathrm{sc}}$. Likewise, $10^{-8} \mathrm{M}$ VIP added to $10^{-6} \mathrm{M} \mathrm{ST}_{\mathrm{a}}$-pretreated monolayers brought the peak $I_{\text {sc }}$ from $15.0 \pm 1.0 \mu \mathrm{A} / \mathrm{cm}^{2}$ to $26.5 \pm 2.5 \mu \mathrm{A} / \mathrm{cm}^{2}$, an $I_{\text {sc }}$ level

Table II. ${ }^{86} \mathrm{R} b^{+}$Efflux in Response to E. coli Heat Stable Enterotoxin: Inhibition by $\mathrm{Ba}^{2+}$

\begin{tabular}{|c|c|c|c|c|c|c|}
\hline \multirow[b]{2}{*}{ Group } & \multirow{2}{*}{$\begin{array}{l}\text { Experimental } \\
\text { condition }\end{array}$} & \multirow[b]{2}{*}{ Period } & \multicolumn{2}{|c|}{${ }^{86} \mathrm{Rb}^{+}$Efflux rate constant } & \multirow[b]{2}{*}{$I_{\mathbf{x}}$} & \multirow[b]{2}{*}{$\mathbf{G}$} \\
\hline & & & Serosal & Mucosal & & \\
\hline & & & $h$ & $h$ & $\mu e q \cdot h^{-1} \cdot \mathrm{cm}^{-2}$ & $\mathrm{mS} \cdot \mathrm{cm}^{-2}$ \\
\hline \multirow[t]{3}{*}{ I $(n=4)$} & No addition & 1 & $0.57 \pm 0.01$ & $0.08 \pm 0.03$ & $0.02 \pm 0.01$ & $1.0 \pm 0.2$ \\
\hline & No addition & 2 & $0.59 \pm 0.04$ & $0.10 \pm 0.05$ & $0.02 \pm 0.01$ & $0.8 \pm 0.1$ \\
\hline & No addition & 3 & $0.54 \pm 0.10$ & $0.03 \pm 0.01$ & $0.02 \pm 0.01$ & $0.7 \pm 0.1$ \\
\hline \multirow{3}{*}{ II $(n=10)$} & No addition & 1 & $0.58 \pm 0.06$ & $0.03 \pm 0.01$ & $0.03 \pm 0.01$ & $1.0 \pm 0.1$ \\
\hline & No addition & 2 & $0.67 \pm 0.06$ & $0.04 \pm 0.01$ & $0.03 \pm 0.01$ & $0.8 \pm 0.1$ \\
\hline & $\mathrm{ST}_{\mathrm{a}}$ & 3 & $1.22 \pm 0.26 * \neq$ & $0.10 \pm 0.02 * \neq$ & $0.47 \pm 0.01 * \pm$ & $0.9 \pm 0.1^{8}$ \\
\hline \multirow{3}{*}{ III $(n=4)$} & No addition & 1 & $0.57 \pm 0.10$ & $0.07 \pm 0.01$ & $0.04 \pm 0.01$ & $1.1 \pm 0.1$ \\
\hline & $\mathrm{BaCl}_{2}$ & 2 & $0.54 \pm 0.10$ & $0.04 \pm 0.01^{*}$ & $0.07 \pm 0.04$ & $0.9 \pm 0.1$ \\
\hline & $\mathrm{ST}_{\mathrm{a}}$ and $\mathrm{BaCl}_{2}$ & 3 & $0.44 \pm 0.12$ & $0.07 \pm 0.02$ & $0.11 \pm 0.02^{\ddagger}$ & $1.0 \pm 0.1^{\S}$ \\
\hline
\end{tabular}

Rubidium effluxes across the basolateral (serosal) and apical (mucosal) membranes were measured in the Ussing chamber using monolayers preloaded with ${ }^{86} \mathrm{Rb}^{+}$. Samples were obtained from the bathing media every 5 or 10 min with appropriate replacement. Results are expressed as mean $\pm \mathrm{SE}$ of the number of experiments, $(n)$, in each group. $\mathrm{ST}_{\mathrm{a}}$, if added, was at 45 min after mounting and $\mathrm{BaCl}_{2}$ was at 25 min. The concentration of $\mathrm{ST}_{\mathrm{a}}$ and $\mathrm{BaCl}_{2}$ were $0.25 \mu \mathrm{M}$ and $3 \mathrm{mM}$, respectively. The efflux period 1 represents the average of two consecutive 5-min intervals before the addition of $\mathrm{BaCl}_{2}$, if added (15-25 min after mounting). Period 2 represents the average of two consecutive 5-min intervals starting 10 min after the addition of $\mathrm{BaCl}_{2}$, if added (35-45 min after mounting). Period 3 represents the average of two consecutive periods, one 5-min and one 10-min period, $25 \mathrm{~min}$ after the addition of $\mathrm{ST}_{\mathrm{a}}\left(70-85 \mathrm{~min}\right.$ after mounting). Corresponding short circuit $\left(I_{\mathrm{sc}}\right)$ which reflects net $\mathrm{Cl}^{-}$secretion and conductance $(\mathrm{G})$ are shown. The monolayers were calculated to contain about $742 \mathrm{nM}$ of $\mathrm{K}^{+}$using ${ }^{86} \mathrm{Rb}^{+}$as a tracer at the beginning of the experiment. ${ }^{*} P<0.05$ by Student's paired $t$ test as compared to period I of the same group. ${ }^{\ddagger} P<0.05$ by Student's unpaired $t$ test as compared to the same period in group I. ${ }^{8} P<0.05$ for $\Delta \mathrm{G}$ between period 3 vs. period 2 as compared to $\Delta \mathrm{G}$ in group I. 


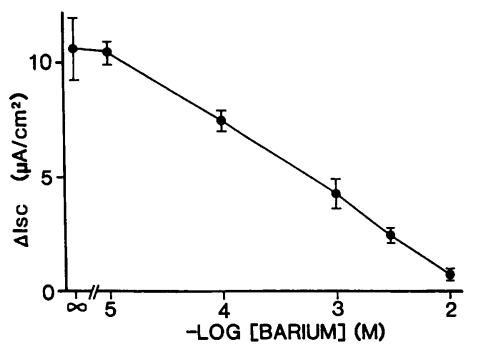

Figure 4. Graded dose effect of barium for inhibition of $\mathrm{ST}_{\mathrm{a}}$-stimulated $I_{\mathrm{sc}}$. $I_{\mathrm{sc}}$ reflects net $\mathrm{Cl}^{-}$secretion across $T_{84}$ monolayers. Varying concentrations of barium were added serosally 15 min after mounting. $0.25 \mu \mathrm{M} \mathrm{ST}_{\mathrm{a}}$ was added to the mucosal reservoir at 35 min after mounting following the barium pretreatment. The results are expressed as the peak change in the $I_{\mathrm{sc}}$ observed within $35 \mathrm{~min}$ after $\mathrm{ST}_{\mathrm{a}}$ addition and represent the mean $\pm \mathrm{SE}$ of four experiments in each group. Only one concentration of barium was tested in each monolayer. Precipitation of barium was observed at concentrations of 3 and $10 \mathrm{mM}$. Therefore, the concentration of barium chloride in the solution is overestimated at these concentrations.

similar to that induced by $10^{-8} \mathrm{M}$ VIP alone $(28.0 \pm 1.0$ $\mu \mathrm{A} / \mathrm{cm}^{2}$ ). The above findings regarding the action of $\mathrm{ST}_{\mathrm{a}}$ and carbachol were similar to those reported previously for $\mathrm{PGE}_{1}$ and carbachol (11) or VIP and A23187 (12).

A complimentary study was carried out with ${ }^{86} \mathrm{Rb}^{+}$-preloaded monolayers grown on culture dishes as described previously (15). In these studies, ${ }^{86} \mathrm{Rb}^{+}$efflux was quantitated in the presence of ouabain with or without bumetanide. The study allowed us to determine if the increase in ${ }^{86} \mathrm{Rb}^{+}$efflux is dependent on the $\mathrm{Na}^{+}, \mathrm{K}^{+}, \mathrm{Cl}^{-}$cotransport mechanism and the $\mathrm{Na}^{+}, \mathrm{K}^{+}$-ATPase pump. The findings are summarized in Fig. 5 . Similar increases in ${ }^{86} \mathrm{Rb}^{+}$efflux were observed with $2.5 \times 10^{-7}$ $\mathrm{M} \mathrm{ST}_{\mathrm{a}}$ in the presence of ouabain alone or in the presence of ouabain and bumetanide. The other words, the bumetanide sensitive effluxes, which represent effluxes of ${ }^{86} \mathrm{Rb}^{+}$via the $\mathrm{Na}^{+}, \mathrm{K}^{+}, \mathrm{Cl}^{-}$cotransport carrier, were not affected by $\mathrm{ST}_{\mathrm{a}}$. Therefore, the increase in ${ }^{86} \mathrm{Rb}^{+}$efflux induced by $\mathrm{ST}_{\mathrm{a}}$ must have occurred via another transport pathway, most likely that $\mathrm{K}^{+}$channel. Taken together, our results suggest that $\mathrm{ST}_{\mathrm{a}}$ activates a $\mathrm{K}^{+}$transport pathway which is sensitive to cAMP, but not the one which is sensitive to $\mathrm{Ca}^{2+}$. The results also suggest that the opening of the $\mathrm{K}^{+}$transport pathway is an effect of $\mathrm{ST}_{\mathrm{a}}$ independent of the $\mathrm{Na}^{+}, \mathrm{K}^{+}, \mathrm{Cl}^{-}$cotransport pathway and the $\mathrm{Na}^{+}, \mathrm{K}^{+}$-ATPase pump.

Uptake studies. Uptake studies were carried out for two purposes. First, ${ }^{36} \mathrm{Cl}^{-}$uptakes were performed to test whether the $\mathrm{Cl}^{-}$channel is opened by the $\mathrm{ST}_{\mathrm{a}}$ and if so, how the magnitude of this effect compared with that produced by VIP. Second, ${ }^{86} \mathrm{Rb}^{+}$uptakes were assayed, in the presence of ouabain with or without bumetanide, to reassess whether the $\mathrm{Na}^{+}, \mathrm{K}^{+}, \mathrm{Cl}^{-}$cotransporter pathway is directly activated by $\mathrm{ST}_{\mathrm{a}}$.

For the first purpose, initial rates of ${ }^{36} \mathrm{Cl}^{-}$uptakes were determined under conditions that favor the uptake of ${ }^{36} \mathrm{Cl}^{-}$ through $\mathrm{Cl}^{-}$channel mediated processes. Dose-dependent activation of the apical-localized $\mathrm{Cl}^{-}$channel by VIP can readily be detected using this method. Similarly, application of $\mathrm{ST}_{\mathrm{a}}$

Table III. ${ }^{86} \mathrm{Rb}{ }^{+}$Efflux in Response to E. coli Heat Stable Enterotoxin: Additive Effect of Carbachol

\begin{tabular}{|c|c|c|c|c|c|c|}
\hline \multirow[b]{2}{*}{ Group } & \multirow[b]{2}{*}{ Experimental condition } & \multirow[b]{2}{*}{ Period } & \multicolumn{2}{|c|}{${ }^{86} \mathrm{Rb}^{+}$Efflux rate constant } & \multirow[b]{2}{*}{$I_{\mathbf{x}}$} & \multirow[b]{2}{*}{$\mathbf{G}$} \\
\hline & & & Serosal & Mucosal & & \\
\hline & & & \multicolumn{2}{|c|}{$h$} & $\mu e q \cdot h^{-1} \cdot \mathrm{cm}^{-2}$ & $m S \cdot \mathrm{cm}^{-2}$ \\
\hline \multirow[t]{3}{*}{ I } & No addition & 1 & $0.65 \pm 0.10$ & $0.03 \pm 0.01$ & $0.04 \pm 0.02$ & $0.66 \pm 0.06$ \\
\hline & $\mathrm{ST}_{\mathrm{a}}$ & $\underline{2}$ & $\underline{1.21 \pm 0.29^{*}}$ & $\underline{0.09 \pm 0.03}$ & $\underline{0.37 \pm 0.02^{*}}$ & $\underline{0.75 \pm 0.06}$ \\
\hline & & $\Delta$ & $0.66 \pm 0.19$ & $0.06 \pm 0.02$ & $0.33 \pm 0.02$ & $0.09 \pm 0.03$ \\
\hline \multirow[t]{3}{*}{ II } & No addition & 1 & $0.55 \pm 0.09$ & $0.03 \pm 0.01$ & $0.03 \pm 0.01$ & $0.93 \pm 0.31$ \\
\hline & Carbachol & $\underline{2}$ & $\underline{0.95 \pm 0.10^{*}}$ & $\underline{0.06 \pm 0.02}$ & $\underline{0.13 \pm 0.02^{*}}$ & $\underline{0.83 \pm 0.26}$ \\
\hline & & $\Delta$ & $0.40 \pm 0.03$ & $0.03 \pm 0.02$ & $0.10 \pm 0.01$ & $-0.10 \pm 0.05$ \\
\hline \multirow[t]{3}{*}{ III } & No addition & 1 & $0.66 \pm 0.07$ & $0.05 \pm 0.01$ & $0.05 \pm 0.02$ & $0.78 \pm 0.21$ \\
\hline & Carbachol and $\mathrm{ST}_{\mathrm{a}}$ & $\underline{2}$ & $\underline{1.66 \pm 0.26}^{*}$ & $\underline{0.09 \pm 0.01}$ & $\underline{1.00 \pm 0.08^{*}}$ & $\underline{1.08 \pm 0.66^{*}}$ \\
\hline & & $\Delta$ & $1.00 \pm 0.20$ & $0.04 \pm 0.02$ & $0.95 \pm 0.07$ & $0.30 \pm 0.07$ \\
\hline \multirow[t]{3}{*}{ IV } & No addition & 1 & $0.68 \pm 0.11$ & $0.05 \pm 0.02$ & $0.04 \pm 0.02$ & $0.66 \pm 0.07$ \\
\hline & VIP & $\underline{2}$ & ${\underline{1.09 \pm 0.13^{*}}}^{*}$ & $\underline{0.11 \pm 0.02^{*}}$ & $\underline{0.62 \pm 0.06^{*}}$ & $\underline{0.86 \pm 0.06^{*}}$ \\
\hline & & $\Delta$ & $0.41 \pm 0.13$ & $0.06 \pm 0.02$ & $0.58 \pm 0.05$ & $0.20 \pm 0.11$ \\
\hline \multirow[t]{3}{*}{ V } & No addition & 1 & $0.67 \pm 0.10$ & $0.05 \pm 0.01$ & $0.03 \pm 0.01$ & $0.69 \pm 0.06$ \\
\hline & VIP and $\mathrm{ST}_{\mathrm{a}}$ & $\underline{2}$ & $\underline{1.29 \pm 0.25^{*}}$ & $\underline{0.11 \pm 0.03}$ & $\underline{0.75 \pm 0.03^{*}}$ & $\underline{0.97 \pm 0.06}^{*}$ \\
\hline & & $\Delta$ & $0.62 \pm 0.21$ & $0.06 \pm 0.02$ & $0.72 \pm 0.03$ & $0.28 \pm 0.06$ \\
\hline
\end{tabular}

Rubidium effluxes across the basolateral (serosal) and apical (mucosal) membranes were measured in the Ussing chamber using monolayers preloaded with ${ }^{86} \mathrm{Rb}^{+}$. Samples were obtained every 5 or $10 \mathrm{~min}$ from the bathing media with appropriate replacement. Results are expressed as mean $\pm \mathrm{SE}$ of 4 experiments in each group. $\mathrm{ST}_{\mathrm{a}}$, carbachol, and VIP, if added, were at $45 \mathrm{~min}$ after mounting. The concentrations of $\mathrm{ST}_{\mathrm{a}}$, carbachol, and VIP were $0.25 \mu \mathrm{M}, 0.1 \mathrm{mM}$ and $0.1 \mu \mathrm{M}$, respectively. Previous studies indicate that maximal $I_{\mathrm{sc}}$ responses were induced by the compounds at these concentrations except for $\mathrm{ST}_{\mathrm{a}}$ which gave a near maximal response (Fig. 2, references 9, 12, 13). The efflux period 1 represents the average of two consecutive 5-min intervals before the addition of any drug (35-45 min after mounting). For comparison, period 2 in all groups represents the average of three consecutive 5 -min intervals followed by two 10-min intervals starting 5 min after the addition of drug(s) (50-85 min after mounting). Corresponding short circuit $\left(I_{\mathrm{sc}}\right)$ and conductance $(\mathrm{G})$ are shown. The monolayers were calculated to contain about $750 \mathrm{nM}$ of ${ }^{86} \mathrm{Rb}^{+}$at the beginning of the experiment. ${ }^{*} P<0.05$ by Student's paired $t$ test as compared to period 1 of the same group. 


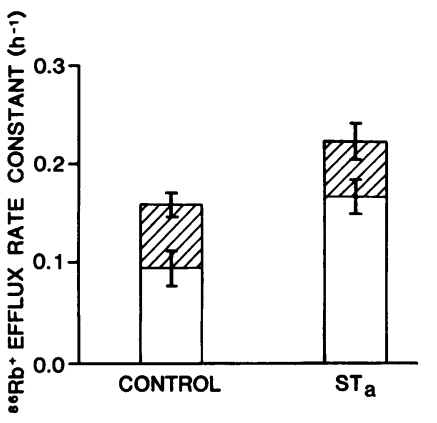

Figure 5. Stimulation of bumetanide-insensitive ${ }^{86} \mathrm{Rb}^{+}$efflux by $\mathrm{ST}_{\mathrm{a}}$. Efflux of ${ }^{86} \mathrm{Rb}^{+}$ from preloaded, ouabaintreated $\mathrm{T}_{84}$ cell monolayers attached to 35-mm culture dishes was determined in the presence or absence of 0.25 $\mu \mathrm{M} \mathrm{ST}_{\mathrm{a}}$ and/or $0.1 \mathrm{mM}$ bumetanide as described in Methods. Effluxes were stopped after 15- and 30-min intervals. Under these conditions, ${ }^{86} \mathrm{Rb}^{+}$efflux appears to follow first order kinetics. The apparent first order rate constants observed in the presence or absence of $\mathrm{ST}_{\mathrm{a}}$ and in the presence (clear portion) or absence (striped plus clear portion) of bumetanide. The results represent the mean \pm SD of three determinations. Under these conditions, $0.25 \mu \mathrm{M} \mathrm{ST}_{\mathrm{a}}$ had no effect on bumetanide sensitive ${ }^{86} \mathrm{Rb}$ efflux, but increased the rate of bumetanide-insensitive ${ }^{86} \mathrm{Rb}$ efflux almost twofold. This increase was similar to, but slightly less than that observed with $10 \mathrm{nM}$ VIP under identical conditions (data not shown).

activated the $\mathrm{Cl}^{-}$channel in a dose-dependent manner. The dose-response curve was nearly identical to that observed for $\mathrm{ST}_{\mathrm{a}}$ 's effect on $I_{\mathrm{sc}}$ (data not shown). However, even at saturating doses $(1 \mu \mathrm{M}), \mathrm{ST}_{\mathrm{a}}$ required at least $30 \mathrm{~min}$ to achieve $90 \%$ maximal stimulation of the $\mathrm{Cl}^{-}$channel (Fig. 6). This contrasts with the action of VIP which gives $\sim 90 \%$ maximal stimulation within $5 \mathrm{~min}$. Thus, the action of $\mathrm{ST}_{\mathrm{a}}$ is slower than that observed with VIP, agreeing with the rather sluggish response to $\mathrm{ST}_{\mathrm{a}}$ in the Ussing chamber. Furthermore, even at supramaximal doses of $\mathrm{ST}_{\mathrm{a}}(1 \mu \mathrm{M})$ and optimal stimulation times (30-60 min), the extent of $\mathrm{Cl}^{-}$channel activation by $\mathrm{ST}_{\mathrm{a}}$ was only $73 \pm 4 \%$ that observed with saturating doses of VIP. These data are similar to the peak $I_{\mathrm{sc}}$ values produced by $\mathrm{ST}_{\mathrm{a}}$ and VIP in the Ussing chamber.

To address the second purpose, ${ }^{86} \mathrm{Rb}^{+}$uptakes were carried out in the presence or absence of prior stimulation by $1 \mu \mathrm{M}$ $\mathrm{ST}_{\mathrm{a}}$ under conditions designed to optimize ${ }^{86} \mathrm{Rb}^{+}$uptake through the $\mathrm{Na}^{+}, \mathrm{K}^{+}, \mathrm{Cl}^{-}$cotransporter and minimize extrane-

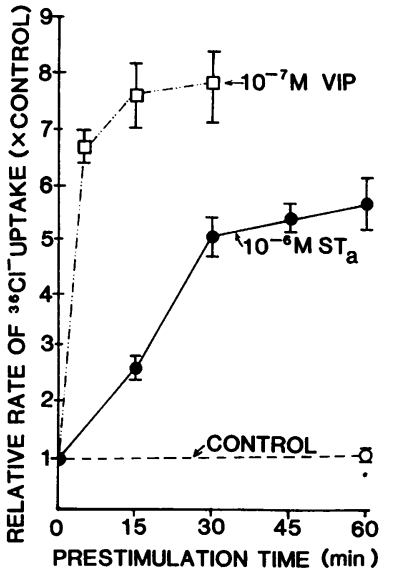

Figure 6. Time course of $\mathrm{ST}_{\mathrm{a}}$ activation of $\mathrm{Cl}^{-}$channel-mediated ${ }^{36} \mathrm{Cl}^{-}$uptake. Confluent monolayer cultures of $T_{84}$ cells attached to $35 \mathrm{~mm}$ culture dishes were assayed for ${ }^{36} \mathrm{Cl}^{-}$uptake as described in Methods. Cells were treated with either $10^{-6} \mathrm{M} \mathrm{ST}_{\mathrm{a}}(\bullet)$ or $10^{-8} \mathrm{M}$ VIP (口), for the times shown, in the $\mathrm{KCl}$ preincubation buffer and immediately assayed for ${ }^{36} \mathrm{Cl}^{-}$uptake in $\mathrm{K}$ gluconate buffer containing $1 \mu \mathrm{Ci} / \mathrm{ml}^{36} \mathrm{Cl}^{-}$. The values shown were normalized to control levels of uptake (o) and represent the mean \pm SD of triplicate determinations made after 15 and $30 \mathrm{~s}$ of uptake. Control levels of ${ }^{36} \mathrm{Cl}^{-}$uptake were $4.46 \pm 0.52 \mathrm{nmol} / \mathrm{min} \cdot \mathrm{mg}$ protein, after taking into account the amount of extracellular $\mathrm{Cl}^{-}$remaining on the plates $(275 \mathrm{nmol}$ $\mathrm{Cl}^{-} / \mathrm{mg}$ protein). ous effects on ion gradients produced by opening of the $\mathrm{K}^{+}$and $\mathrm{Cl}^{-}$channel (Table IV). After a 30-min stimulation, there was no detectable effect on the initial rate of bumetanide-sensitive ${ }^{86} \mathrm{Rb}^{+}$uptake. Even though these conditions are suboptimal for uptake via the $\mathrm{K}^{+}$channels (15) there was a small but significant increase in the bumetanide-insensitive ${ }^{86} \mathrm{Rb}^{+}$uptake which can probably be attributed to ${ }^{86} \mathrm{Rb}^{+}$uptake through the $\mathrm{K}^{+}$channels. After a 60 -min stimulation with $\mathrm{ST}_{\mathrm{a}}$, there was a small $16 \%$ decrease in bumetanide-sensitive ${ }^{86} \mathrm{Rb}^{+}$uptake. This decrease can probably be attributed to a loss in cell volume due to the efflux of cellular $\mathrm{K}^{+}$and $\mathrm{Cl}^{-}$through the $\mathrm{K}^{+}$ and $\mathrm{Cl}^{-}$channels $(15,16)$. This data agrees with the effect of $\mathrm{ST}_{\mathrm{a}}$ on ${ }^{86} \mathrm{Rb}^{+}$efflux from ouabain-treated preloaded cells (Fig. 5). Together, these data strongly suggest that $\mathrm{ST}_{\mathrm{a}}$ does not directly affect the activity of the $\mathrm{Na}^{+}, \mathrm{K}^{+}, \mathrm{Cl}^{-}$cotransporter in $T_{84}$ cells. The data do not address a probably indirect activation of the cotransporter through changes in intracellular ion concentrations.

The effect of $S T_{a}$ on secondary messengers. To further explore the mechanism of action of $\mathrm{ST}_{\mathrm{a}}$, we measured the effect of the enterotoxin on cellular cAMP, cGMP, and free cytosolic $\mathrm{Ca}^{2+}\left(\left[\mathrm{Ca}^{2+}\right]_{\mathrm{i}}\right)$ in the presence and absence of VIP or carbachol. The results are summarized in Table V. ST $\mathrm{a}$ and carbachol had no effect on cellular cAMP, while VIP increased cAMP. This increase in cAMP by VIP was not altered by $\mathrm{ST}_{\mathrm{a}}$. In contrast, $\mathrm{ST}_{\mathrm{a}}$ increased cellular cGMP while VIP and carbachol had no effect. The increase in cGMP by $\mathrm{ST}_{\mathrm{a}}$ was not altered by either VIP or carbachol. The time course and graded dose effect of cGMP production and the increase in $I_{\mathrm{sc}}$ in response to $\mathrm{ST}_{\mathrm{a}}$ are shown in Fig. 7. The changes in $I_{s c}$ correlated well with the changes in CGMP, while cAMP levels did not change, indicating that CGMP did not cross-react in the cAMP assay, or vice versa. In addition, neither VIP nor $\mathrm{ST}_{\mathrm{a}}$ increased $\left[\mathrm{Ca}^{2+}\right]_{\mathrm{i}}$, nor did they augment carbachol-induced changes in $\left[\mathrm{Ca}^{2+}\right]_{\mathrm{i}}$. These results suggest that the action of $\mathrm{ST}_{\mathrm{a}}$ is mediated by cGMP alone. The results also suggest that the ability of $\mathrm{ST}_{\mathrm{a}}$ or VIP to

Table IV. Effect of $S T_{a}$ on Bumetanide-sensitive ${ }^{86} R b^{+}$Uptake

\begin{tabular}{cccc}
\hline & \multicolumn{2}{c}{${ }^{86} \mathrm{Rb}^{+}$Uptake } & \\
\cline { 2 - 3 } $\begin{array}{c}\text { Length of exposure } \\
\text { to ST. }\end{array}$ & $\begin{array}{c}\text { Without } \\
\text { bumetanide }\end{array}$ & $\begin{array}{c}\text { With 0.1 mM } \\
\text { bumetanide }\end{array}$ & $\begin{array}{c}\text { Bumetanide-sensitive } \\
\text { (derived) }\end{array}$ \\
\hline min & \multicolumn{3}{c}{ nmol/3 min per mg protein } \\
\\
0 & $79.5 \pm 2.5$ & $1.3 \pm 0.1$ & \\
30 & $82.9 \pm 1.9$ & $1.8 \pm 0.1$ & $78.2 \pm 2.5$ \\
60 & $67.0 \pm 2.0$ & $1.6 \pm 0.0$ & $65.4 \pm 2.0$
\end{tabular}

The effect of $\mathrm{ST}_{\mathrm{a}}$ on bumetanide-sensitive ${ }^{86} \mathrm{Rb}^{+}$uptake. Confluent monolayer cultures of $\mathrm{T}_{84}$ cells were preincubated as described in Methods with $1.0 \mu \mathrm{M} \mathrm{ST}_{\mathrm{a}}$ included in the final preincubation buffer for the duration indicated. The total preincubation time in sucrose buffer was $1.0 \mathrm{~h}$ in each case. The initial rate of ${ }^{86} \mathrm{Rb}^{+}$uptake was determined in triplicate using 3-min uptake periods in the presence or absence of $0.1 \mathrm{mM}$ bumetanide. The bumetanide-sensitive portion of ${ }^{86} \mathrm{Rb}^{+}$uptake decreased significantly only after $60 \mathrm{~min}$ exposure to $\mathrm{ST}_{\mathrm{a}}$. Replicate plates were assayed for CGMP content which increased from $0.7 \mathrm{pmol} / \mathrm{mg}$ protein to over $300 \mathrm{pmol} / \mathrm{mg}$ protein after 30 min exposure to $\mathrm{ST}_{\mathrm{a}}$. 
Table V. Measurement of Secondary Messengers in $S T_{a}$-Treated $T_{84}$ Monolayers

\begin{tabular}{|c|c|c|c|}
\hline Experiment & cGMP Level & cAMP Level & $\Delta\left[\mathrm{Ca}^{2+}\right]_{\mathrm{i}}$ \\
\hline & pmol $\cdot \mathrm{mg}_{\text {protein }}-1$ & $\mathrm{pmol} \cdot \mathrm{mg}$ protein $^{-1}$ & $n M$ \\
\hline Control & $<1.8$ & $4.2 \pm 1.0$ & $<5.0$ \\
\hline $0.25 \mu \mathrm{M} \mathrm{ST}_{\mathrm{a}}$ & $314.8 \pm 50.9^{*}$ & $2.9 \pm 1.2$ & $<5.0$ \\
\hline $0.1 \mu \mathrm{M}$ VIP & $<1.8$ & $458.9 \pm 42.5^{*}$ & $<5.0$ \\
\hline $0.1 \mathrm{mM}$ carbachol & $<1.8$ & $3.5 \pm 0.6$ & $45.6 \pm 5.5^{*}$ \\
\hline $\begin{array}{l}0.25 \mu \mathrm{M} \mathrm{ST} \\
\quad+0.1 \mu \mathrm{M} \text { VIP }\end{array}$ & $378.4 \pm 65.0^{*}$ & $493.2 \pm 47.8^{*}$ & $<5.0$ \\
\hline $\begin{array}{l}0.25 \mu \mathrm{M} \mathrm{ST} \\
\quad+0.1 \mathrm{mM} \text { carbachol }\end{array}$ & $343.5 \pm 63.6^{*}$ & $3.1 \pm 0.4$ & $51.7 \pm 7.5^{*}$ \\
\hline
\end{tabular}

Various secretagogues were added alone or in combination at the concentrations indicated. For the cyclic nucleotide measurements, $T_{84}$ cells were preincu bated for $15 \mathrm{~min}$ with the indicated agents as described in Methods before the measurement; no addition was made to the control group. The results are expressed as means $\pm \mathrm{SE}$ of five to six experiments in each group. For free cytosolic $\mathrm{Ca}^{2+}\left(\left[\mathrm{Ca}^{2+}\right]_{\mathrm{i}}\right)$ measurements the monolayers were loaded with Fura-2/ $\mathrm{AM}$ for $90 \mathrm{~min}$ and fluorescence was then measured continuously in the presence of the various secretagogues as described in Methods. Results are expressed as means $\pm \mathrm{SE}$ of the difference between the peak free cytosolic $\mathrm{Ca}^{2+}$ value in response to the secretagogue(s) and the baseline value. Baseline values for free cytosolic $\mathrm{Ca}^{2+}$ were $62.0 \pm 5.1 \mathrm{nM}$. All experiments were carried out with monolayers on permeable support. Monolayers grown on culture dish also exhibit similar responses to $0.1 \mu \mathrm{M}$ VIP [427.5 $\pm 74.4 \mathrm{pmol} \cdot \mathrm{mg} \operatorname{protein}^{-1}$ $(n=6)]$ and $0.25 \mu \mathrm{M} \mathrm{ST}_{\mathrm{a}}\left[288 \pm 66.8 \mathrm{pmol} \cdot \mathrm{mg} \mathrm{protein}^{-1}(n=3)\right]$

${ }^{*} P<0.05$ by Student's unpaired $t$ test as compared to control.

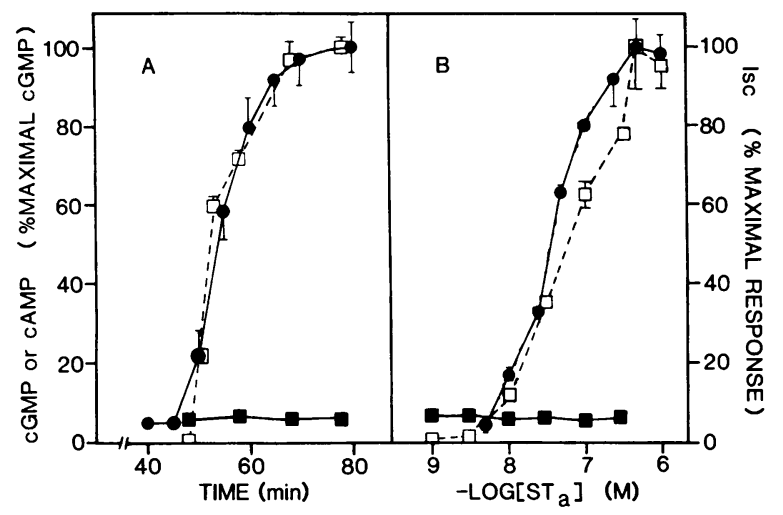

Figure 7. Time course $(A)$ and graded dose effect $(B)$ of $E$. coli heat stable enterotoxin $\left(\mathrm{ST}_{\mathrm{a}}\right)$ on the changes in cyclic nucleotide concentration (cGMP or cAMP). The changes in $I_{\mathrm{sc}}$ reflective of net $\mathrm{Cl}^{-}$secretion (•) shown for comparison as percent maximal response are the same as in Figs. 1 and 2. The concentration of $\mathrm{ST}_{\mathrm{a}}$ in the time study was $2.5 \times 10^{-7} \mathrm{M}$. Cyclic nucleotide measurements were carried out on $\mathrm{T}_{84}$ monolayers prepared in the same manner as for the Using chamber experiments. The results are expressed as means $\pm \mathrm{SE}$ of at least three experiments for each concentration of $\mathrm{ST}_{\mathrm{a}}$. The maximal responses for the $I_{\mathrm{sc}}$ and cGMP in the time study were $13.4 \pm 0.9 \mu \mathrm{A} / \mathrm{cm}^{2}$ and $228.7 \pm 6.0 \mathrm{pmol} / \mathrm{mg}$ protein, respectively. The maximal responses for the $I_{\mathrm{sc}}$ and cGMP in the dose, response study were $14.3 \mu \mathrm{A} / \mathrm{cm}^{2}$ and $213.6 \pm 1.4 \mathrm{pmol} / \mathrm{mg}$ of protein, respectively. Only one concentration of $\mathrm{ST}_{\mathrm{a}}$ was tested in each monolayer. The same extract from each monolayer was used to determine both cGMP ( $\square$ ) and cAMP ( $\square$ ) concentrations. cAMP concentrations are expressed relative to the maximal cGMP concentration in each experiment. For the dose response studies, the monolayers were extracted for cGMP and cAMP $35 \mathrm{~min}$ after $\mathrm{ST}_{\mathrm{a}}$ addition when the $\mathrm{I}_{\mathbf{s c}}$ response was at its peak. potentiate carbachol's action on $I_{\mathrm{sc}}$ cannot be explained by changes in either $\left[\mathrm{Ca}^{2+}\right]_{i}$, cAMP or cGMP alone.

\section{Discussion}

In this report, we first demonstrated that $T_{84}$ monolayers respond to $\mathrm{ST}_{\mathrm{a}}$ in a manner similar to that occurring in isolated intestine $(1,5)$. Having done so, this cell line was used as a model system to study the $\mathrm{Cl}^{-}$secretory mechanism mediated by this enterotoxin and cGMP.

In contrast to other secretagogues which cause $\mathrm{Cl}^{-}$secretion only when applied to the basolateral surface of $\mathrm{T}_{84}$ cells, $\mathrm{ST}_{\mathrm{a}}$ was effective only when added to the apical surface. This result suggests that receptors for $\mathrm{ST}_{\mathrm{a}}$ are preferentially localized to the apical membrane. This conclusion is supported by receptor binding assays that demonstrate binding of the enterotoxin to apical membrane receptors leading to activation of guanyl cyclase in a dose-dependent manner (30). In this study, both the time course and graded dose effect for $\mathrm{Cl}^{-}$secretion induced by $\mathrm{ST}_{\mathrm{a}}$ paralleled the increase in the cellular cGMP level. In addition, there was no change in cAMP or free cytosolic $\mathrm{Ca}^{2+}$ in the presence of $\mathrm{ST}_{\mathrm{a}}$. These findings strongly suggest that cGMP is the secondary messenger mediating the $\mathrm{Cl}^{-}$ secretory effect of $\mathrm{ST}_{\mathrm{a}}$.

Next, we identified the transport pathways affected by $\mathrm{ST}_{\mathrm{a}}$. Previous studies have defined two sites for hormonal regulation of the $\mathrm{Cl}^{-}$secretory process across $\mathrm{T}_{84}$ monolayers: $(a)$ The basolaterally localized $\mathrm{K}^{+}$channel, which serves to recycle $\mathrm{K}^{+}$, and $(b)$ The apically localized $\mathrm{Cl}^{-}$channel, which serves as the $\mathrm{Cl}^{-}$exit pathway. $\mathrm{ST}_{\mathrm{a}}$ activates a $\mathrm{K}^{+}$transport pathway on the basolateral membrane and also increases $\mathrm{Cl}^{-}$exit across $\mathrm{Cl}^{-}$channels on the apical membrane. Increased activity of the $\mathrm{Na}^{+}, \mathrm{K}^{+}$-ATPase and the $\mathrm{Na}^{+}, \mathrm{K}^{+}, \mathrm{Cl}^{-}$cotransporters, which we believe are secondary, could be inferred by the ability of ouabain and bumetanide to inhibit or reverse the action of this enterotoxin. This pattern of activation by $\mathrm{ST}_{\mathrm{a}}$ resembles the mechanism of action of cAMP but is different from that mediated by $\mathrm{Ca}^{2+}$. Our discussion will focus on the two regulatory sites, the $\mathrm{K}^{+}$and $\mathrm{Cl}^{-}$channels.

Increased exit of $\mathrm{Cl}^{-}$through the apical $\mathrm{Cl}^{-}$channel was reflected by the electrogenic nature of $\mathrm{Cl}^{-}$secretion as well as the increase in bidirectional $\mathrm{Cl}^{-}$fluxes in the presence of $\mathrm{ST}_{\mathrm{a}}$. Because the occluding junction structure of this model epithelium has a very high resistance (8), we believe that the increased bidirectional $\mathrm{Cl}^{-}$fluxes across $\mathrm{T}_{84}$ monolayers largely result from an increased transcellular movement of $\mathrm{Cl}^{-}$. In other words, $\mathrm{Cl}^{-}$flux was a result of an increase in $\mathrm{Cl}^{-}$exit through the $\mathrm{Cl}^{-}$channel on the apical membrane as well as an increase in $\mathrm{Cl}^{-}$uptake by the $\mathrm{Na}^{+}, \mathrm{K}^{+}, \mathrm{Cl}^{-}$cotransport carrier across the basolateral membrane. Both pathways must be functional to allow a selective increase in transcellular $\mathrm{Cl}^{-}$ fluxes. Either inhibition of the $\mathrm{Na}^{+}, \mathrm{K}^{+}, \mathrm{Cl}^{-}$cotransporter by bumetanide or blockage of the $\mathrm{Cl}^{-}$channel reversed the cAMP- or cGMP-mediated mechanisms. It should be noted that blockage of the basolaterally localized $\mathrm{K}^{+}$channel by barium also effectively inhibited net $\mathrm{Cl}^{-}$secretion. Although barium inhibited net $\mathrm{Cl}^{-}$secretion it did not reverse the increase in unidirectional $\mathrm{Cl}^{-}$fluxes induced by cyclic nucleotides as was the case with inhibition of the $\mathrm{Cl}^{-}$channel or the $\mathrm{Na}^{+}, \mathrm{K}^{+}, \mathrm{Cl}^{-}$cotransport pathway. This finding suggests that the $\mathrm{Cl}^{-}$channel and the $\mathrm{Na}^{+}, \mathrm{K}^{+}, \mathrm{Cl}^{-}$cotransport pathway are regulated independently of the $\mathrm{K}^{+}$channel. 
The $\mathrm{ST}_{\mathrm{a}}$-mediated effect on $\mathrm{Cl}^{-}$transport, although closely resembling the cAMP-mediated mechanism, differed in at least two respects. The time interval required to observe maximal effects of $\mathrm{ST}_{\mathrm{a}}$ on either net $\mathrm{Cl}^{-}$secretion or ${ }^{36} \mathrm{Cl}$ uptake through opening of the $\mathrm{Cl}^{-}$channels, was longer than that observed with effectors acting through cAMP. Since there was a correlation between the rise in $I_{\mathrm{sc}}$ and the increase in cGMP, this result implies that the intracellular mechanisms by which $\mathrm{ST}_{\mathrm{a}}$ activates guanylate cyclase are slower than the mechanisms coupling VIP or $\mathrm{PGE}_{1}$ receptors to adenylate cyclase. The maximal effect of $\mathrm{ST}_{\mathrm{a}}\left(10^{-6} \mathrm{M}\right)$ on either net $\mathrm{Cl}^{-}$secretion or ${ }^{36} \mathrm{Cl}^{-}$uptake through the $\mathrm{Cl}^{-}$channels was less than that maximally produced by VIP $\left(10^{-8} \mathrm{M}\right)$. This result implies that cGMP may be less effective than cAMP in activating the protein kinase(s) responsible for opening the $\mathrm{Cl}^{-}$channel. Alternately, it could be argued that cGMP and cAMP open different sets of $\mathrm{Cl}^{-}$channels. The finding that the combined $I_{\mathrm{sc}}$ effect of cGMP and cAMP (ST ${ }_{\mathrm{a}}$ plus VIP) approximated that induced by cAMP (VIP) alone argues against the latter proposal.

The opening of $\mathrm{K}^{+}$efflux pathway on the basolateral membrane by $\mathrm{ST}_{\mathrm{a}}$ has been demonstrated in this study. This process can be blocked by $\mathrm{Ba}^{2+}$, a K${ }^{+}$channel blocker, but is not sensitive to inhibition by tetraethylammonium chloride, 4-aminopyridine, or apamin. Quinidine, which may release $\mathrm{Ca}^{2+}$ from an intracellular store, increased the $I_{\mathrm{sc}}$ before exerting an inhibitory action. The sensitivity pattern of this $\mathrm{K}^{+}$ efflux pathway, including the graded dose effect of barium inhibition, resembles that of a cAMP-sensitive pathway reported earlier for VIP and $\mathrm{PGE}_{1}(11,15)$ but differs from that of a $\mathrm{Ca}^{2+}$-mediated mechanism reported for carbachol (13). We have also shown that $\mathrm{K}^{+}$efflux induced by $\mathrm{ST}_{\mathrm{a}}$ is not additive to that induced by VIP but is additive to that induced by carbachol. Taken together these findings suggest that the same $\mathrm{K}^{+}$channel is activated by both cAMP and cGMP. The critical involvement of this $\mathrm{K}^{+}$efflux pathway in the $\mathrm{Cl}^{-}$secretory process is demonstrated by the fact that blockage of this pathway inhibited net $\mathrm{Cl}^{-}$secretion. The depolarization of the cell, caused by the efflux of $\mathrm{K}^{+}$, may be a necessary feature required to drive $\mathrm{Cl}^{-}$exit across the apical membrane (10).

Recently, inhibition or stimulation of the $\mathrm{Na}^{+}, \mathrm{K}^{+}, \mathrm{Cl}^{-}$cotransport mechanism by atrial natriuretic factor (ANF) and 8-Br-cGMP but not cAMP has been suggested by other investigators (31-33), thus leading us to investigate this pathway. When $\mathrm{Cl}^{-}$secretion across the $\mathrm{T}_{84}$ monolayer increased, an increased activity of this cotransport pathway can be assumed as it is the $\mathrm{Cl}^{-}$uptake pathway. We were unable to demonstrate that $\mathrm{ST}_{\mathrm{a}}$ caused any direct changes in bumetanide-sensitive ${ }^{86} \mathrm{Rb}^{+}$efflux or bumetanide-sensitive ${ }^{36} \mathrm{Cl}^{-}$uptake in the presence of ouabain. Concurrently, we were able to demonstrate an increase in bumetanide-insensitive ${ }^{86} \mathrm{Rb}^{+}$efflux and bumetanide-insensitive ${ }^{86} \mathrm{Rb}^{+}$uptake as well as an increase in cellular cGMP by $\mathrm{ST}_{\mathrm{a}}$. The results suggest that the $\mathrm{Na}^{+}, \mathrm{K}^{+}, \mathrm{Cl}^{-}$ cotransport mechanism is not directly activated by $\mathrm{ST}_{\mathrm{a}}$. The presumed increase in its activity requires an active $\mathrm{Na}^{+}, \mathrm{K}^{+}$ ATPase pump and is probably secondary to the favorable gradient created by $\mathrm{K}^{+}$and $\mathrm{Cl}^{-}$exits, primary regulatory processes activated by $\mathbf{S T}_{\mathbf{a}}$.

Our studies suggest that $\mathrm{ST}_{\mathrm{a}}$-induced $\mathrm{Cl}^{-}$secretion is mediated by cGMP. Its mechanism of action resembles that of cAMP (VIP and PGE ${ }_{1}$ ) despite the different localization of their receptor-cyclase activation. Table VI summarizes the re-
Table VI. Comparison of $C A M P-, c G M P$ and $\mathrm{Ca}^{2+}$ Mediate Secretory Response in $T_{84}$ Cells

\begin{tabular}{|c|c|}
\hline Secretory mechanism & Transport pathways regulated \\
\hline cAMP-mediated & Apical $\mathrm{Cl}^{-}$channel \\
\hline $\begin{array}{l}\left(\mathrm{VIP}, \mathrm{PGE}_{1}, \text { high }\right. \\
\text { concentration of } \\
\text { adenosine })\end{array}$ & $\begin{array}{l}\text { Basolateral }\left(\mathrm{Ba}^{2+} \text { sensitive) } \mathrm{K}^{+} \text {channel. }\right. \\
\text { (both presumably cyclic-nucleotide } \\
\text { dependent) }\end{array}$ \\
\hline cGMP-mediated & Apical $\mathrm{Cl}^{-}$channel \\
\hline$\left(\mathrm{ST}_{\mathrm{a}}\right)$ & $\begin{array}{l}\text { Basolateral } \mathrm{K}^{+} \text {channel }\left(\mathrm{Ba}^{2+} \text { sensitive) }\right. \\
\text { (both presumably cyclic-nucleotide } \\
\text { dependent similar to cAMP- } \\
\text { mediated response) }\end{array}$ \\
\hline $\begin{array}{l}\mathrm{Ca}^{2+} \text {-mediated (carbachol, } \\
\text { histamine) }\end{array}$ & $\begin{array}{l}\text { Basolateral } \mathrm{K}^{+} \text {channel }\left(\mathrm{Ba}^{2+}\right. \\
\text { insensitive) presumably } \mathrm{Ca}^{2+} \\
\text { dependent }\end{array}$ \\
\hline
\end{tabular}

All three mechanisms involve the $\mathrm{Na}^{+}, \mathrm{K}^{+}, \mathrm{Cl}^{-}$cotransport on the basolateral membrane, which serve as the $\mathrm{Cl}^{-}$uptake mechanism and the $\mathrm{Na}^{+}, \mathrm{K}^{+}$ATPase pump. Utilizing ${ }^{36} \mathrm{Cl}^{-}$uptake and efflux studies, we were unable so far to demonstrate an opening of apical $\mathrm{Cl}^{-}$channel by $\mathrm{Ca}^{2+}$-mediated response. It is assumed, therefore, that $\mathrm{Cl}^{-}$was secreted via the $\mathrm{Cl}^{-}$channels that are randomly open. Patch clamp studies should clarify this point in the future.

sults of our investigation on regulatory mechanism of $\mathrm{Cl}^{-}$secretion in the $T_{84}$ cell to date. The $T_{84}$ model epithelium may facilitate further investigation of $\mathrm{ST}_{\mathrm{a}}$-related pathobiology.

\section{Acknowledgments}

The authors wish to thank Dr. Kim Barrett for her helpful suggestions and her aid in editing the manuscript, Mr. Greg Beuerlein for technical assistance, and Mr. Gary L. Deming for typing the manuscript.

The study was supported by grant AM-28305 from the National Institutes of Health, a grant from the National Ileitis and Colitis Foundation, a grant from the Cystic Fibrosis Foundation and VA Project No. 539-3108-01 from the Veterans Administration. Mr. Patrick A. Huott and Mr. Wilson Liu were supported by Student Summer Research Fellowships from the American Gastroenterological Association. Dr. Kiertisin Dharmsathaphorn is a recipient of a National Institutes of Health Research Career Development Award (AM-01146) and an American Gastroenterological Association/Glaxo Research Scholar Award.

\section{References}

1. Rao, M. C., S. A. Orellana, M. Field, D. C. Robertson, and R. A. Giannella. 1981. Comparison of the biological actions of three purified heat-stable enterotoxins: effects on ion transport and guanylate cyclase activity in rabbit ileum in vitro. Infect. Immun. 33:165-170.

2. Giannella, R. A., and K. W. Drake. 1979. Effect of purified Escherichia coli heat-stable enterotoxin on intestinal cyclic nucleotide metabolism and fluid secretion. Infect. Immun. 24:19-23.

3. Spiegel, A. M., P. Gierschik, M. A. Levine, and R. W. Downs, Jr. 1985. Clinical implications of guanine nucleotide-binding proteins as receptor-effector couplers. N. Engl. J. Med. 312:24-33.

4. Guandalini, S., M. Migliavacca, E. de Campora, and A. Rubino. 1982. Cyclic guanosine monophosphate effects on nutrient and electrolyte transport in rabbit ileum. Gastroenterology. 83:15-21.

5. Guandalini, S., M. C. Rao, P. L. Smith, and M. Field. 1982. 
cGMP modulation of ileal ion transport: in vitro effects of Escherichia coli heat-stable enterotoxin. Am. J. Physiol. 243:G36-G41.

6. Rao, M. C., N. T. Nash, and M. Field. 1984. Differing effects of cGMP and cAMP on ion transport across flounder intestine. Am. J. Physiol. 246:C167-C171.

7. Dharmsathaphorn, K., K. G. Mandel, J. A. McRoberts, L. D. Tisdale, H. Masui. 1984. A human colonic tumor cell line that maintains vectorial electrolyte transport. Am. J. Physiol. 246:C204-C208.

8. Madara, J., and K. Dharmsathaphorn. 1985. Occluding junction structure-function relationships in a cultured human colonic cell monolayer. J. Cell Biol. 101:2124-2133.

9. Dharmsathaphorn, K., J. A. McRoberts, H. Masui, and K. G. Mandel. 1985. Vasoactive intestinal polypeptide-induced chloride secretion by a colonic epithelial cell line. Direct participation of a basolaterally localized $\mathrm{Na}^{+}, \mathrm{K}^{+}, \mathrm{Cl}^{-}$cotransport system. J. Clin. Invest. 75:462-471.

10. Mandel, K. G., J. A. McRoberts, G. Beuerlein, E. S. Foster, and K. Dharmsathaphorn. 1986. $\mathrm{Ba}^{++}$inhibition of VIP and A23187 stimulated $\mathrm{Cl}^{-}$secretion by $\mathrm{T}_{84}$ cell monolayers. Am. J. Physiol. 250:C486-C494.

11. Weymer, A., P. Huott, W. Liu, J. A. McRoberts, and K. Dharmsathaphorn. 1985. Chloride secretory mechanism induced by prostaglandin $\mathrm{E}_{1}$ in a colonic epithelial cell line. J. Clin. Invest. 76:1828-1836.

12. Cartwright, C. A., J. A. McRoberts, K. G. Mandel, and K. Dharmsathaphorn. 1985. Synergistic action of cyclic AMP and calcium mediated chloride secretion in a colonic epithelial cell line. $J$. Clin. Invest. 76:1837-1842.

13. Dharmsathaphorn, K., and S. J. Pandol. 1986. Mechanism of chloride secretion induced by carbachol in a colonic epithelial cell line. J. Clin. Invest. 77:348-354.

14. Dharmsathaphorn, K., P. Huott, C. A. Cartwright, J. A McRoberts, K. G. Mandel, and G. Beuerlein. 1986. Inhibition of cAMP and ATP levels by quinidine in a human colonic epithelial cell line. Am. J. Physiol. 250:G806-G813.

15. McRoberts, J. A., G. Beuerlein, and K. Dharmsathaphorn. 1985. Cyclic AMP and $\mathrm{Ca}^{++}$activated $\mathrm{K}^{+}$transport in a human colonic epithelial cell line. J. Biol. Chem. 260:14163-14172.

16. Mandel, K. G., K. Dharmsathaphorn, and J. A. McRoberts. 1986. Characterization of a cyclic AMP-activated $\mathrm{Cl}^{-}$transport pathway in the apical membrane of a human colonic epithelial cell line. $J$. Biol. Chem. 261:704-712.

17. Ammon, H., and K. Dharmsathaphorn. 1986. Mechanism of action of bile salts on colonic $\mathrm{Cl}^{-}$secretion: a study based on a cultured epithelial model. Clin. Res. 34:436a. (Abstr.)

18. Wasserman, S., P. Huott, K. Barrett, G. Beuerlein, M. Kagnoff, and $\mathrm{K}$. Dharmsathaphorn. 1988. Immune-related intestinal $\mathrm{Cl}^{-}$secretion: I. Effect of histamine on the $\mathrm{T}_{84}$ cell line. Am. J. Physiol. 254:C53-C62.

19. Garty, H., B. Rudy, and S. J. D. Karlish. 1983. A simple and sensitive procedures for measuring isotopic fluxes through ion-specific channels in heterogeneous populations of membrane vesicles. J. Biol. Chem. 258:13094-13099.

20. Tsien, R. Y., T. J. Rink, and M. Poenie. 1985. Measurement of cytosolic free $\mathrm{Ca}^{+2}$ in individual small cells using fluorescence microscopy with dual excitation wavelengths. Cell. Calcium. 6:145-157.

21. Poenie, M., J. Alderton, R. Tsien, and R. A. Steinhardt. 1985. Changes of free calcium levels with stages of the cell division cycle. Nature (Lond.). 315:147-149.

22. Staples, S. J., S. E. Asher, and R. A. Giannella. 1980. Purification and characterization of heat-stable enterotoxin produced by a strain of E. coli pathogenic for man. J. Biol. Chem. 255:4716-4721.

23. Thompson, M. R., M. Luttrell, G. Overmann, and R. A. Giannella. 1985. Biological and immunlogical characteristics of ${ }^{125} \mathrm{I}-4 \mathrm{Tyr}$ and -18 Tyr Escherichia coli heat-stable enterotoxin species purified by high-performance liquid chromatography. Anal. Biochem. 148:26-36.

24. Thompson, M. R., and R. A. Giannella. 1985. Revised amino acid sequence for a heat-stable enterotoxin produced by an Escherichia coli strain (18D) that is pathogenic for humans. Infect. Immun. 47:834-836.

25. Snedecor, G. W., and W. G. Cochran. 1967. Statistical Methods. Sixth edition. Iowa State University Press, Ames, IA.

26. Giannella, R. A., P. Huott, and K. Dharmsathaphorn. 1987. Reversal of E. coli heat-stable enterotoxin-induced secretion and guanylate cyclase activation by anti-ST monoclonal antibody. Gastroenterology. 92:1403. (Abstr.)

27. McLennan, W. L., T. E. Machen, and T. Zeuthen. 1980. Ba ${ }^{2+}$ inhibition of electrogenic $\mathrm{Cl}^{-}$secretion in vitro frog and piglet gastric mucosa. Am. J. Physiol. 239:G151-G160.

28. Rangachari, P. K. 1975 . $\mathrm{Ba}^{++}$on the resting frog stomach effects on electrical and secretory parameters. Am. J. Physiol. 228:511-517.

29. Wangemann, P., M. Wittner, A. DiStefano, H. C. Englert, H. J. Lang, E. Schlatter, and R. Greger. 1986. $\mathrm{Cl}^{-}$channel blockers in the thick ascending limb of the loop of Henle. Structure activity relationship. Pfluegers Arch. 407(Suppl. 2):S128-141.

30. Guarino, A., M. Cohen, M. Thompson, K. Dharmsathaphorn, and R. Giannella. 1987. $T_{84}$ cell receptor binding and guanyl cyclase activation by E. coli heat-stable toxin. Am. J. Physiol. 250:G775G780.

31. O'Grade, S. M., M. Field, N. T. Nash, and M. C. Rao. 1985. Atrial natriuretic factor inhibits $\mathrm{Na}-\mathrm{K}-\mathrm{Cl}$ cotransport in teleost intestine. Am. J. Physiol. 249:C531-C534.

32. Rao, M. C., and N. T. Nash. 1986. 8-Br-Cyclic AMP (Br-cA) does not affect $\mathrm{Na} / \mathrm{K} / \mathrm{Cl}$ cotransport in the flounder intestine. Fed. Proc. 45:890 (Abstr.).

33. O'Donnell, M. E., and N. E. Owen. 1986. Atrial natriuretic factor (ANF) stimulated $\mathrm{Na} / \mathrm{K} / \mathrm{Cl}$ cotransport in vascular smooth muscle cells (VSMC). Fed. Proc. 45:653. (Abstr.) 